\title{
PUENTES Y MIGRACIONES
}

\author{
HIBRIDACIÓN Y RECURSOS INTERTEXTUALES COMO \\ PRÁCTICAS APROPIACIONISTAS EN LA OBRA DE ALEXIS \\ CÁRDENAS.
}

Tesista: Adriana Díaz Lezama

Directora: María Elena Larrégle 
Dedicada a mi familia y a la memoria de mi hermana. 


\section{INDICE}

AGRADECIMIENTOS....................................................... 5

INTRODUCCION ........................................................................ 6

\section{PRIMERA PARTE}

CAPITULO I

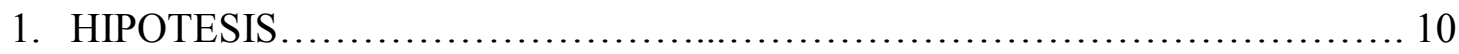

2. OBJETIVOS.

2.1 Objetivos Generales................................................. 11

2.2 Objetivos Específicos....................................................... 11

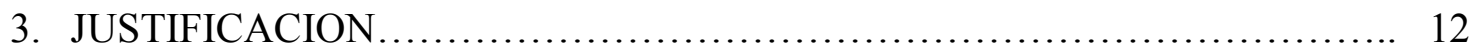

4. ANTECEDENTES CONSULTADOS ................................... 14

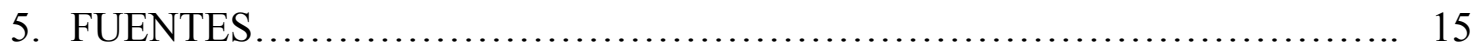

CAPITULO II

6. MARCO TEORICO

6.1 Prácticas Apropiacionistas................................................ 16

6.2 Hibridación.............................................................. 18

6.3 Transexualidad e Intertextualidad......................................... 21

\section{CAPITULO III}

7. METODOLOGÍA

7.1 Universo y Unidad de Análisis........................................... 26

7.2 Criterios de Selección de los Ejemplos Musicales............................ 27

\section{SEGUNDA PARTE}

CAPITULO IV

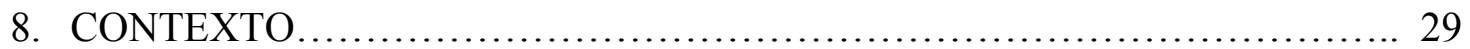

8.1 Análisis musical de los temas seleccionados ............................ 30

8.1.1 Capriccio No 16 de Nicolo Paganini.................................. 32

8.1.2 Pajarillo Con Moto y Acelerando (Brahms/Bach/Trad.).............. 44 


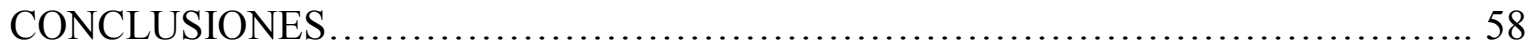

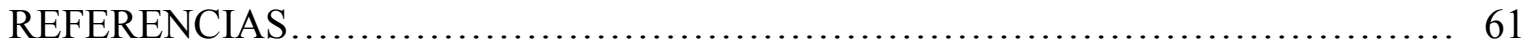

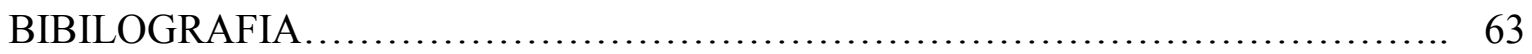

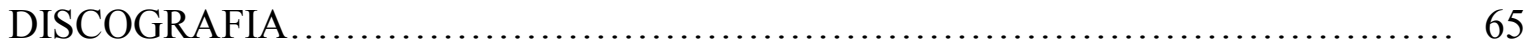

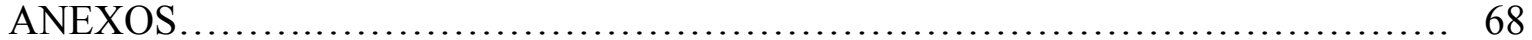




\section{AGRADECIMIENTOS}

A mi directora de tesis Maria Elena Larrégle, un profundo agradecimiento por interesarse en mi proyecto y decidir acompañarme en este proceso. Sus observaciones y comentarios siempre claros y oportunos fueron fundamentales para poder concretar y materializar este trabajo.

También agradezco a la Maestría en Estética y Teoría de las Artes y a sus profesores, pues cada seminario fue un vehículo que me permitió conocer y descubrir una nueva perspectiva sobre el arte, y me dio herramientas para atreverme a explorar otros caminos y miradas con respecto a la música.

Por supuesto un inmenso agradecimiento al Maestro Alexis Cárdenas, no sólo porque su música inspiró esta investigación, sino porque también me ofreció de manera muy amable y afectuosa su tiempo y su voz, y me dio la oportunidad de conocer de primera mano sus ideas con respecto al arte, la música y la vida.

Enormemente agradecida también con mi padre Mario y mi hermano Ernesto, ya que con su colaboración y revisión, las transcripciones de las piezas no resultaron ser una tarea tan ardua.

Por último, quiero agradecer a mi familia y en especial a mi madre Margarita, mi abuela Helvia y mi tía Luisa por su amor, impulso y apoyo incondicional. 


\section{INTRODUCCIÓN}

Alexis Cárdenas es un violinista venezolano (Maracaibo, 1976) que dentro de su propuesta musical busca integrar a la música académica con la música popular. Es un artista polifacético con una trayectoria destacada a nivel internacional, ya que desde corta edad se ha distinguido como intérprete de música clásica, música contemporánea, jazz y música latinoamericana. Además, uno de sus grandes intereses es difundir la creación de compositores latinoamericanos y dar a conocer obras para violín de compositores contemporáneos. Por ejemplo, en el año 2019 fue el violinista escogido para interpretar el estreno mundial del Concierto para Violín y Orquesta del compositor colombiano Gustavo Parra. ${ }^{1}$ Además, recientemente (dic. 2020) lanzó en colaboración con el pianista, compositor y jazzista venezolano Leo Blanco ${ }^{2}$ un disco llamado "Stories Without Words" de músicas de Latinoamérica.

Esta inquietud lo ha llevado a desarrollar varios proyectos en los cuales, valiéndose de diferentes procedimientos, hace una hibridación de géneros, instrumentos y temporalidades que resulta especial en cuanto a cómo re interpretar o re contextualizar una obra. Además, estas apropiaciones son construidas a través de la combinación de obras icónicas de la música occidental con ritmos de la música popular venezolana como un modo de manifestar su idea de que, dentro de la música, no debería haber clases o estratificaciones.

Para estas apropiaciones, podemos afirmar que Alexis, por un lado, toma prestados temas de la música académica europea y los transforma y fusiona con géneros y ritmos de música

\footnotetext{
${ }^{1}$ Compositor, arreglista, docente y director de orquesta nacido en Ipiales, Nariño en 1963.

${ }^{2}$ Compositor y pianista nacido en Mérida, Venezuela. Actualmente es profesor de piano en Berklee College of Music en Boston.
} 
latinoamericana y, por otro lado, recoge piezas del repertorio de la música tradicional venezolana y latinoamericana, que versiona para un violín "codificado con elementos de conservatorio"3

Esta investigación parte de la base de que este tipo de tratamiento sobre la música ocurre como resultado del proceso migratorio de Alexis Cárdenas, ya que el intercambio cultural que él ha experimentado le ha permitido acercar y construir puentes para integrar a los sectores musicales hegemónicos con los populares. Alexis Cárdenas busca, de alguna manera, el reconocimiento y la reivindicación de la música popular con respecto al estatus de la música académica europea considerando que hace falta difundir más a los compositores e intérpretes latinoamericanos y ponerlos al mismo nivel.

La idea de este proyecto nace a partir de la expectativa de ofrecer un análisis de la música que no transite por el estudio de las formas y/o lo histórico, sino que aborde de manera distinta las obras. Esta nueva perspectiva permite acercarse a las creaciones y posturas estéticas de la práctica musical de los siglos XX y XXI para dilucidar cuáles han sido los procesos de renovación, re-significación y re-contextualización del discurso musical.

Así las cosas, la pregunta que surge a partir del contexto anterior es cómo Alexis Cárdenas utiliza la hibridación como forma de producción, y cómo vincula algunas categorías del lenguaje literario por medio de recursos intertextuales para renovar y re-dimensionar las obras que selecciona interpreta.

A partir de este interrogante surgen otras preguntas que se pretenden responder en el desarrollo de esta investigación y tienen que ver con:

\footnotetext{
${ }^{3}$ Alexis afirma que la música que él interpreta es el resultado de sus experiencias y del contacto con los ritmos populares y tradicionales latinoamericanos, sin desconocer que su formación ha sido académica; con lo cual, el repertorio de estudio y los elementos técnicos para la ejecución del violín tienen claramente el sello del aprendizaje occidental heredado de las escuelas europeas.
} 
1. ¿Cómo relata y caracteriza Alexis Cárdenas su proceso creativo y su producto?

2. ¿Cuáles son sus motivaciones y sus criterios de selección del material con el que va a trabajar en una obra?

3. ¿Cuáles son las características comunes tanto a nivel musical como formal, que le permiten hacer la hibridación de dos estilos musicales tan distintos? (en cuanto a lo cultural y lo temporal)

4. ¿Bajo qué estrategias de hibridación realiza Alexis Cárdenas la producción de sus obras?

Uno de los conceptos que utilizaré para sustentar y dar respuesta a estas preguntas es el de Hibridación. Alfonso de Toro es uno de los autores que aborda este tema y plantea que la hibridez es una conditio de nuestro ser, pensar y actuar globalizado, que se materializa en diversos campos del conocimiento y en diversas disciplinas.

En el mundo globalizado actual constatamos que hibridez es la conditio de nuestro ser, pensar y actuar que se concretiza en diversos campos del conocimiento y en diversas disciplinas con diferentes aplicaciones, siendo asimismo el resultado de múltiples estrategias de hibridación discursiva, artística, política, sociológica, filosófica, medial..., que hacen posible una negociación o el cotidiano lidiar de la diferencia y alteridad. (Toro, 2005, p.1).

De otro lado, me apoyaré en las teorías del lenguaje literario planteadas por el escritor y teórico literario Francés Gerard Genette, quién utiliza el concepto de Transtextualidad para definir la trascendencia textual del texto. (Genette, 1989). Es decir, que es todo aquello que relaciona explícita o implícitamente a un texto con otros. Dentro de las categorías de la teoría transtextual, la que se abordará para el análisis de los temas musicales de Alexis Cárdenas es la Intertextualidad. A través de algunos ejemplos se mostrará la utilización de algunos rasgos como la cita y el collage, recursos que Alexis Cárdenas ejecuta con procedimientos como el montaje, 
la superposición y la transformación. Así, se podrá ver cómo se utilizan dos o más textos dentro de su discurso musical que al superponerlos generan uno nuevo.

Para esta investigación se tomarán como objeto de análisis dos piezas musicales contenidas en la producción musical Bicho y hecho (2001), correspondiente a uno de los proyectos musicales de Alexis Cárdenas llamado Ensamble Recoveco, para mostrar cómo él utiliza estas técnicas dentro de su proceso creativo dándole otra dimensión estética y temporal a su obra. 


\section{PRIMERA PARTE}

\section{CAPITULO I}

\section{HIPÓTESIS}

1.1 Los procesos de renovación, re-significación y re-contextualización en la producción de Alexis Cárdenas ocurren como resultado de su proceso migratorio y de la versatilidad como artista que esto le ha brindado, ya que al empaparse y apropiarse de varios géneros en este intercambio cultural, se da como resultado el acercamiento e integración de los sectores musicales hegemónicos con los populares.

1.2 La producción de Alexis Cárdenas puede abordarse bajo algunas categorías del concepto de hibridación. Por una parte, desde la categoría o estrategia transmedial, ya que utiliza diversos sistemas, formas de comunicación y estéticas que implican un proceder transcultural y transtextual, y por otra parte desde la estrategia teórico cultural, ya que en su propuesta se da el encuentro y la conjunción de diversas culturas, así como géneros musicales que proceden de diferentes continentes, épocas y estilos.

1.3 Desde un análisis comparativo entre los recursos intertextuales que se utilizan en el lenguaje literario y los textos o citas de la literatura musical, puede afirmarse que, para hacer su práctica de hibridación, Alexis Cárdenas utiliza procedimientos equiparables a la cita y el collage y los pone en acto desde recursos compositivos como el montaje, la superposición y la transformación. 


\section{OBJETIVOS}

\subsection{Generales}

2.1.1 Analizar los procesos de renovación, re-significación y re-contextualización presentes en la obra del violinista Alexis Cárdenas.

2.1.2 Mostrar el significado de la hibridación como forma de producción.

2.1.3 Identificar y analizar cuáles son las categorías del lenguaje literario utilizadas para construir procedimientos de hibridación entre música europea para violín y ritmos tradicionales de la música latinoamericana.

\subsection{Específicos}

2.2.1 Indagar cuál es la postura estética de Alexis Cárdenas y cómo ve él las prácticas apropiacionistas de la creación artística reciente en cuanto a heterogeneidades, sincronías, préstamos, transferencias y migraciones.

2.2.2 Identificar y caracterizar qué tipo de estrategias de hibridación utiliza Alexis Cárdenas en su proceso creativo.

2.2.3 Describir cuáles son los rasgos intertextuales que utiliza Alexis Cárdenas por medio del análisis de algunos ejemplos de la producción musical Bicho y Hecho (2001) del Ensamble Recoveco. 


\section{JUSTIFICACIÓN}

Dentro de la praxis musical, los préstamos de material y la utilización de ciertos recursos o rasgos intertextuales suelen ser utilizados por diferentes compositores para actualizar las obras y reinterpretarlas. Es así, que al ponerlas en otro contexto, tiempo y lugar, se puede cambiar su sentido y darles otra dimensión. Como afirma George Steiner (1993), dentro de la praxis y al interior de la propia música es posible y legítima la crítica, así que algunos recursos como el tema y variaciones, las re-orquestaciones o las citas, son utilizados de manera muy frecuente y desde tiempos antiguos como una manera de ampliar el significado de una obra y de introducirla en un nuevo contexto estético.

Desde finales del siglo XX, en América Latina se han desarrollado y esparcido de manera significativa varios proyectos de músicas y géneros que buscan fusionarse para dar vida a otros nuevos. Como ejemplo de este fenómeno podemos mencionar la cumbia-electrónica, el jazz mezclado con ritmos de las costas atlántica y pacífica colombiana, proyectos de rap y jazz, tango electrónico y muchas otras propuestas que resultan de la experimentación con diferentes tipos de lenguaje, por lo que el tema está muy vigente hoy en día. Además, puede decirse que esto ocurre sobre todo en el terreno práctico más que a nivel teórico, ya que hay mucha creación y grupos en desarrollo de sus propuestas.

Así las cosas, esta investigación resulta innovadora ya que se aborda una experiencia musical concreta de hibridación entre música académica europea para violín con música llanera venezolana, logrando no sólo un cruce de géneros e instrumentos distintos, sino también de culturas, temporalidades y estilos de interpretación. (Entre lo académico europeo y lo popular latinoamericano). 
Además, es oportuna ya que abre un espacio para la comprensión de estos procesos de hibridación pero desde otra perspectiva. Muchas de las investigaciones musicales se realizan tomando como centro de estudio el concepto de mestizaje, y en este tipo de análisis el enfoque está principalmente en los procesos históricos, religiosos y étnicos que influencian el contexto en el cuál se desarrollan las obras.

Por el contrario, este proyecto se basa en la hibridación ya es un concepto amplio que puede ser aplicado tanto como técnica de producción, así como desde una perspectiva socio cultural, ya que reúne más tipos de mezclas y procesos interculturales.

En este sentido, Nestor García Canclini explica que la hibridación agrupa una constelación de conceptos tales como Modernidad-modernización-modernismo, diferencia-desigualdad, heterogeneidad multitemporal y reconversión entro muchos otros. (García, 1997). 


\section{ANTECEDENTES CONSULTADOS}

De la gran variedad de material consultado para la realización de este trabajo, hay que resaltar tres textos que resultaron fundamentales como antecedentes en cuanto al enfoque de análisis y el tratamiento del tema de la intertextualidad y de las prácticas de apropiación.

El primer texto, Rasgos intertextuales en la música académica de la segunda mitad del siglo XX. La cita, la alusión y la parodia como procedimientos arquetípicos y el pasado como archivo en la creación contemporánea. (Mansilla, 2013), hace el análisis de algunas obras académicas posmodernas, donde se evidencia el uso de procedimientos apropiacionistas que toman vida a través de la utilización de algunos rasgos como la cita, la alusión y la parodia.

El siguiente texto, El puesto de la intertextualidad en los estudios musicales. (Hatten, 1994), se centra en el uso de la intertextualidad desde un enfoque teórico y analítico, donde por medio de algunos ejemplos, se muestra como a través del tiempo y de los diferentes periodos de la historia de la música, la práctica intertextual ha ido cambiando su enfoque y sus recursos se han utilizado partiendo desde la concepción de homenaje, hasta darle un sentido de apropiación crítica.

Finalmente, el texto "Cita y collage, Literatura e Intertextualidad en Berio". TERCER MOVIMIENTO DE SINFONÍA (1968). (Delgado, 2012), hace un análisis muy detallado del tercer movimiento de esta obra, lo cual permite entender de una manera muy explícita la superposición de estilos musicales anacrónicos, el uso de un lenguaje híbrido, el carácter dialógico del discurso y como un texto siempre se ha basado en textos anteriores. 


\section{FUENTES}

Como parte del proceso de estructuración del marco de referencia, se realizó una revisión y recolección de fuentes primarias y secundarias que están directamente relacionadas con el proyecto.

En cuanto a las fuentes primarias, se contó con la fortuna de poder realizar una entrevista a Alexis Cárdenas, lo cual permitió conocer de su propia voz los aspectos más importantes de su trabajo y de su postura estética y creativa. De otro lado, se usaron las grabaciones del disco Bicho y Hecho del Ensamble Recoveco, para iniciar el proceso de transcripción y de creación de las partituras de los dos temas seleccionados para este trabajo, esto con el fin de poder ofrecer un análisis musical y formal mucho más detallado.

Finalmente, se contó con la posibilidad de asistir en varias oportunidades a conciertos de Alexis Cárdenas con diferentes agrupaciones, siendo esta experiencia previa importante, pues facilitó hacerse una idea de cuál era la propuesta musical de este artista.

Con respecto a las fuentes secundarias, se hizo una extensa consulta de bibliografía con el fin de seleccionar los diferentes textos que aportaron al fundamento teórico de este trabajo, también se revisaron algunas entrevistas previas que le habían realizado a Alexis Cárdenas diferentes medios, al igual que algunas reseñas de conciertos, programas de mano y noticias de internet, todo esto para complementar los resultados de la investigación. 


\section{CAPITULO II}

\section{MARCO TEÓRICO}

\subsection{Prácticas Apropiacionistas}

El marco teórico de esta investigación se basa fundamentalmente en tres conceptos. El primero de ellos es el concepto de Prácticas Apropiacionistas, y para abordarlo me he apoyado en un texto del filósofo español Juan Martín Prada, quien nos presenta la idea de una Apropiación Crítica Posmoderna. El autor afirma que este concepto, visto desde una dimensión social, abarca un extenso espacio de heterogeneidades, sincronías, préstamos, transferencias y migraciones de la creación artística reciente. Enfoca la práctica artística posmoderna hacia una visión crítica y plantea que desde este encuadre se tiene una actitud de revisión y relectura de lo dado, es decir, que va más allá del plano de la estética referencial e historicista. (Prada, 2001).

"No es el concepto de transmisión de las imágenes, estilos y pautas estéticas a través del tiempo el que opera aquí sino, sobre todo, el de su reubicación contextual.” (Prada, 2001, p.1). Tomo este concepto porque creo que es la base teórica de donde se desprenden los otros dos conceptos que mencionare más adelante.

En Alexis Cárdenas, este pensamiento apropiacionista parte de la base de que él es un sujeto que ha tenido contacto con múltiples expresiones culturales, ha viajado mucho y esto le ha permitido tener muchas experiencias e influencias artísticas. Como afirma Roland Barthes, un texto está constituido por un espacio de múltiples dimensiones en el que se concuerdan y se contrastan diversas escrituras, siendo así el texto un tejido de citas provenientes de los mil focos de la cultura. (Barthes, 1984). 
Además, el hecho de no querer encasillarse (como intérprete y violinista) en algún género musical o época, le permite acercarse al conocimiento con apertura y flexibilidad, lo cual le ha llevado por el camino estético que se expone en este trabajo.

Para Alexis Cárdenas, la mezcla es el fundamento de su pensamiento musical y su manera de abordar el lenguaje es producto del intercambio cultural al que ha estado expuesto. Él define su propuesta como Música Mestiza pues toma elementos de todos los lenguajes que lo han influenciado y a partir de ahí construye puentes entre la herencia europea, la herencia africana y la indígena.

Somos herederos de toda esa cultura barroca: Bach, Scarlatti, las iglesias, y hasta la forma de comer. Sin embargo no puedo dejar de bailar, de sentir y de darle mi propia puntuación y acentuación a la música europea porque tengo herencia india y negra que sale. $^{4}$

Aparte de esta manera orgánica y espontánea de sentir y de conectarse con la música, él confiesa que utiliza estos procedimientos porque quiere devolverles a los europeos su propia música transformada. Piensa que en Europa el público (sobre todo el joven) está cansado de escuchar lo mismo; es decir, que la música Académica Occidental ya no llama tanto la atención, y no porque no tenga un gran valor sino porque cree que se hace tediosa la repetición, así que propone releerla y reinventarla bajo otra lectura. ${ }^{5}$

Acá podemos ver reflejada claramente la teoría de apropiación de Prada, ya que él afirma:

En realidad, el empleo de un lenguaje de cambios de contexto, de ruptura de los discursos de la temporalidad y de la historia de la tradición, que es común a todas las prácticas de apropiación crítica, trata de implicar al espectador en el cuestionamiento de la naturaleza y el proceso del arte mismo, en el cuestionamiento del status de un objeto como arte y, por tanto, de sus presunciones y presuposiciones institucionales. (Prada, 2001, p.3).

\footnotetext{
${ }^{4}$ Entrevista a Alexis Cárdenas.

${ }^{5}$ Entrevista a Alexis Cárdenas.
} 
Finalmente, otro punto de encuentro entre Alexis Cárdenas y la teoría de apropiación posmoderna es que él no aparta totalmente a la institución ni a la academia, sino que se vale de ella, de su repertorio y de sus recursos técnicos para transformarla y comunicar a partir de estos elementos algo distinto. "Soy un transgresor, me gusta cambiar las cosas y a pesar de los esfuerzos del conservatorio por encaminarme, no lo consiguieron. Hice el conservatorio para después desecharlo, sólo tome lo que necesitaba."6

Por su parte, Prada afirma en este sentido:

No obstante, lejos de plantear el rechazo de la institución a la manera de los neo vanguardismos, los artistas apropiacionistas se apropian de ella, lejos de proponer su disolución, la convierten en campo de operaciones. La experiencia estética queda revelada así como manifestación política, desviada y re-localizada en los márgenes de la historia y del conflicto social. (Prada, 2001, p.5).

\subsection{Hibridación}

El segundo concepto es el de Hibridación que utiliza Alfonso de Toro para referirse a un conjunto de prácticas y/o estructuras que existen de forma separada e independiente pero que se enlazan generando otras nuevas.

La hibridez, constituida por la diferencia y la alteridad, puede ser finalmente entendida dentro de la teoría de la cultura como la estrategia que relaciona y conecta elementos étnicos, sociales y culturales de la Otredad [...] (Toro, 2005, p.2).

Para Toro, la diferencia se puede entender como una aproximación al otro desde una lógica transversal, que reinscribe las contradicciones y no las homogeniza ni excluye, sino que negocia con ellas en un acto de apertura. (Toro, 2005).

\footnotetext{
${ }^{6}$ Entrevista a Alexis Cárdenas
} 
Por su parte, la alteridad se define como una categoría operacional de la diferencia a través de la cual se negocian encuentros concretos y heterogéneos. Es decir que pone a disposición estrategias discursivas para encuentros culturales y para la Otredad. (Toro, 2005).

Describe entonces la hibridez como un concepto amplio que contiene no solo un componente étnico-etnológico, así que hace una clasificación y plantea los siguientes 6 tipos. (Toro, 2005).

1. Hibridez como estrategia epistemológica: forma de pensamiento y/o conocimiento.

2. Hibridez como estrategia científica: Ciencia transversal, procedimientos teóricos y metodológicos.

3. Hibridez como estrategia teórico cultural: Encuentro o concurrencia de colectividades, culturas, etnias, religiones, minorías.

4. Hibridez como estrategia transmedial: Empleo de diversos sistemas, medios y formas de comunicación (internet, video, film, análogo, digital), estéticas y genéricas (literatura, teatro, ensayo), culturas del gusto, arte (pintura, diseño), arquitectura, ciencias (naturales, medicina, biología molecular) y lingüística.

5. Hibridez como estrategia de organización urbano-social y de la vida: Formas de organización en ciudades, compañías, ecología, naturaleza, sociología, religiones, políticas y estilos de vida.

6. Hibridez como el territorio de una estrategia corporal/objetal.

Finalmente, plantea que las estructuras híbridas son complejas ya que confluyen diversos sistemas, diversos tipos de modelos y procedimientos.

Dentro de un concepto transdisciplinario y teórico-cultural resultante de las estrategias de hibridación se pueden establecer puntos de partidas comunes. Así, consideramos como estructuras híbridas aquellas que se caracterizan por su complejidad, por la confluencia de diversos sistemas, por recurrir a diversos tipos de modelos y procedimientos y por una condición básica que se puede definir como la potencialidad de la diferencia en el reconocimiento en una cartografía en común. (Toro, 2005, p.1). 
El pensamiento musical de Alexis Cárdenas se relaciona con esta teoría de la hibridación ya que dentro de su trabajo se busca exaltar, potenciar y reconocer la diferencia. No se prioriza ni se privilegia ningún material, sino que se busca generar un diálogo y una negociación que les permita coexistir.

La estrategia de hibridación apunta a la potencialización de la diferencia y no a su reducción, asimilación, adaptación, en un primer momento. En un segundo momento conduce la estrategia hibridación a un "reconocimiento de la diferencia", esto es, a la posibilidad de negociar identidades diferentes en un tercer espacio. (Toro, 2005, p.3).

De otro lado, García Canclini nos habla de la hibridación como un concepto social que resulta más pertinente utilizar en los estudios culturales, ya que abarca más mezclas interculturales que el concepto de mestizaje (mezcla de etnias y razas) o que el concepto de sincretismo (mezcla y funciones religiosas, culturales o movimientos simbólicos tradicionales). Es interesante como este concepto permite que haya un entrelazamiento entre lo tradicional y lo moderno; lo popular, lo culto y lo masivo y por ende entre las clases cultas y populares. (García, 1997).

Alexis Cárdenas utiliza el recurso de la hibridación para expresar desde lo musical su pensamiento intercultural, logrando crear a partir de diversos códigos culturales, épocas y estilos un lenguaje que integra todos estos elementos en un nuevo discurso musical.

La interculturalidad hace referencia al proceso permanente de encuentro, relación y negociación de grupos sociales con identidades culturales diferentes, sin que esto implique que alguno está por encima del otro. En este sentido, las diferentes manifestaciones son respetadas y se ven de manera horizontal, se basa en condiciones de simetría, equidad e igualdad. Es decir que no hay jerarquías ni privilegios (Walsh, 2010).

El intercambio, la comunicación y el movimiento entre las prácticas culturales permiten que la apropiación, la re elaboración y por lo tanto la hibridación, sean procesos naturales de este encuentro. 
Esta concepción es muy importante en la obra de Alexis Cárdenas ya que es el fundamento de su práctica artística. A través de este pensamiento el hibrida elementos de su tradición cultural con prácticas del pasado y elementos de la modernidad, nutriéndose de varios saberes. Esto genera como resultado la construcción, la re significación y el tejido de nuevas redes.

\subsection{Transtextualidad e Intertextualidad}

Finamente, el tercer concepto tiene que ver con el análisis de las obras desde las categorías del lenguaje literario y para esto se toman como base las teorías del filósofo ruso Mijaíl Bajtín. En sus trabajos sobre teoría de la literatura, él inicia la reflexión sobre el carácter dialógico que tiene todo discurso y de cómo todo emisor ha sido antes receptor de muchos otros textos, de modo que siempre su producción se basará y estará influenciada en textos anteriores (Delgado, 2012).

La crítica literaria francesa Julia Kristeva retoma este concepto y a finales de la década del 60 acuña como tal el término Intertextualidad. Complementa la teoría bajtiana y afirma que cualquier texto futuro no puede ser sino un diálogo con textos anteriores, que todo texto es un intertexto, y que otros textos se encuentran insertos en un texto bajo formas más o menos reconocibles.

Más adelante, en la década de los 80 , Gerard Genette vuelve sobre este tema y establece una clasificación más detallada, ya que amplía el término y sus categorías, las cuales agrupa dentro de un término más vasto como lo es la Transtextualidad. (Genette, 1989).

Este autor utiliza el concepto de Transtextualidad para definir la trascendencia textual del texto. Es decir, que es todo aquello que relaciona, explícita o implícitamente a un texto con otros. Dentro de la transtextualidad, reconoce cinco tipos: Paratextualidad, Metatextualidad, 
Arquitextualidad, Hipertextualidad e Intertextualidad. Algunas de las características más importantes de estos son:

Paratextualidad: Es la relación que el texto propiamente dicho mantiene con su "paratexto": títulos, subtítulos, inter títulos, prefacios, prólogos, epílogos, notas, epígrafes, ilustraciones.

Metatextualidad: Es la relación de comentario que une un texto a otro texto que habla de el sin citarlo e incluso a veces, sin nombrarlo. La crítica es una expresión de esta relación metatextual.

Architextualidad: Conjunto de categorías generales a las que pertenece y con las que se relaciona un texto, como tipos de discurso, modos de enunciación o géneros literarios.

Hipertextualidad: Toda relación que une a un texto B (hipertexto) con un texto anterior A (hipotexto). El que llega al lector (o espectador) es el texto derivado o hipertexto. El hipotexto que está presente implícitamente puede manifestarse de varias formas.

A. Transformación: Un texto deriva de otro; es decir, "se inspira" en otro y a partir de ahí se da la transformación. Puede evocarlo más o menos explícitamente, no necesariamente tiene que hablar de él o citarlo. En la transformación, el hipertexto (o texto derivado) puede eventualmente apartarse del texto original buscando una creación con características propias. Las formas de efectuar la transformación son las siguientes:

i. Parodia: Se interviene el texto y se desvía a costa de unas modificaciones mínimas. Su intención es lúdica. ${ }^{7}$

ii. Travestimiento: Es una transformación cuya función es satírica. Es decir que se conserva el contenido fundamental de un texto, pero se transforma su estilo. ${ }^{8}$

\footnotetext{
${ }^{7}$ Ejemplo: https://www.youtube.com/watch?v=BLXwpGCn2KQ Desde el inicio y hasta el 1' 20s, la orquesta dirigida por el británico Rainer Hercsh interpreta la Obertura "Guillermo Tell" de Giacomo Rossini.
} 
iii. Transposición: Es la transformación más seria de todas las prácticas hipertextuales donde el hipertexto se aparta de su hipotexto. Aquí, la ambición estética o ideológica de la transformación lleva a ocultar o a hacer olvidar su carácter hipertextual. ${ }^{9}$

B. Imitación: Es otro tipo de transformación. Para imitar hay que adquirir un dominio al menos parcial, de los rasgos que se ha decidido imitar. Por lo tanto decimos que la imitación acerca el hipertexto al hipotexto ya que no se pierden las características del texto original. También tenemos tres tipos de Imitación:

iv. Pastiche: Es una de las especies derivadas de la parodia. Consiste en una imitación estilística con una función crítica o ridiculizadora. ${ }^{10}$

v. Caricatura: Es un pastiche satírico, cuya forma generalizada es "A la manera de..."11

vi. Continuación: Es una imitación seria de una obra que tiende a prolongarla o complementarla. ${ }^{12}$

Intertextualidad: Es la relación de co-presencia entre dos o más textos; es decir, la presencia efectiva de un texto en otro. Esto significa que en el hipertexto aparece el hipotexto.

Podemos encontrar tres tipos de intertextualidad:

\footnotetext{
${ }^{8}$ Ejemplo: https://www.youtube.com/watch?v=90OTyDGL2uM Desde el inicio y hasta el 1' 13s, el grupo colombiano Real Charanga introduce un fragmento de la Alemanda en Dm de la Partita para Violín solo N. 2 de Juan Sebastián Bach en su tema llamado Guaguancó.

${ }^{9}$ Ejemplo: https://www.youtube.com/watch?v=1EIE78D0m1g Variaciones de Brahms sobre un tema de Paganini Op. 35 (capricho N. 24)

${ }^{10}$ Ejemplo: https://www.youtube.com/watch?v=JuhSAbQPk7E Rondó "Alla turca" de la Sonata para piano N. 11 en La Mayor de Mozart, inspirado en las bandas de viento y percusión que acompañaban las campañas de las tropas turcas. (En esta versión se está interpretado un instrumento histórico con pedales "Jenízaros" para hacer alusión a la colorida percusión turca).

${ }^{11}$ Ejemplo: https://www.youtube.com/watch?v=gKpFhPdyQLM Desde el 1' 13s y hasta el 3' 50s, el cuarteto polaco mozART toma el tema principal de la Pequeña Serenata nocturna de Mozart y lo interpreta moviéndose por diferentes géneros.

${ }^{12}$ Ejemplo: https://www.youtube.com/watch?v=kkC3chi_ysw Maurice Ravel hace una orquestación de "Los Cuadros de Una Exposición” de Modesto Mussorgsky que es original para piano.
} 
A. Cita: Es la forma más explícita y literal de intertextualidad. Consiste en utilizar en un texto, palabras o párrafos de otro texto (ya sea del mismo autor o de otro autor), con comillas, con o sin referencia precisa. ${ }^{13}$

B. Plagio: Se toman palabras o párrafos sin indicar que le pertenecen a otro autor. Es una copia no declarada pero literal. ${ }^{14}$

C. Alusión: Es un enunciado cuya comprensión supone la existencia de un texto base u original al que se remite necesariamente. El lector o espectador que conoce el hipotexto comprenderá la alusión. El uso de este recurso es muy frecuente en la actualidad, manifestándose en prácticamente todos los tipos de lenguajes artísticos como lo son la literatura, la plástica, la música, el teatro, la danza y las artes audiovisuales por citar algunas. $^{15}$

Esta conceptualización proveniente de la literatura ha propiciado en música el término Intermusicalidad ${ }^{16}$ al cual se ha denominado "Música sobre músicas" y hace referencia a cuando uno o varios textos musicales preexistentes se han reestructurado dándoles un nuevo sentido. Pueden usarse procedimientos como la cita y el collage y así entenderse la intermusicalidad como fusión de músicas en los procesos interculturales.

Debo aclarar que en la praxis musical la utilización de estos recursos ha sido siempre muy común. Durante la edad media por ejemplo, se empezó a utilizar una melodía original o preexistente (cantus firmus) alrededor de las cual se componían o improvisaban otras líneas más

\footnotetext{
${ }^{13}$ Ejemplo: https:/www.youtube.com/watch?v=4EGczv7iiEk Desde el inicio y hasta el 0'9s, la banda The Beatles en su tema All you need is Love, cita un fragmento de La Marsellesa.

${ }^{14}$ Ejemplo: https://www.youtube.com/watch?v=2s4slliAtQU La banda Beach Boys en su tema Surfin USA recurre al plagio. El tema original es de Chuck Berry y se llama Sweet Little Sixteen

https://www.youtube.com/watch?v=ZLV4NGpoy_E

${ }^{15}$ Ejemplo: https://www.youtube.com/watch?v=eqwu2NpbQT8 Richie Ray en el tema Sonido bestial toca un fragmento del Estudio Op. 10 N. 12 "Revolucionario" de Chopin

${ }^{16}$ Ingrid Monson, etnomusicóloga y profesora asistente en el Departamento de Música de la Universidad de Chicago, introduce en 1996 el término "intermusicalidad"
} 
floridas para complementarla ${ }^{17}$. Más adelante en el Renacimiento la composición de madrigales estuvo basada en textos seculares a menudo en italiano ${ }^{18}$. Otro ejemplo lo encontramos durante el siglo XIX con el Movimiento Nacionalista donde los compositores académicos se interesaron y se inspiraron en la música del folklore de su país y la introdujeron de manera sugerente en la música que crearon ${ }^{19}$.

Finalmente podemos destacar el uso de la forma musical Tema y Variaciones, donde a una melodía se le hacen diversos cambios en cuanto al modo, el ritmo, la textura, la velocidad y el carácter ${ }^{20}$. Podemos ver entonces como los compositores han tomado obras de otros músicos o de sí mismos para realizar re-orquestaciones, homenajes y diferentes préstamos creando redes intertextuales amplias que constantemente buscan mostrar otra mirada de la práctica artística.

Los conceptos de Intertextualidad y de Hipertextualidad como parte central de las prácticas transtextuales en la obra de Alexis Cárdenas, los tomo porque son la manera de ejemplificar como él hace uso de la hibridación, como trata los diferentes discursos o textos para resignificarlos. Las categorías del lenguaje literario y varios de sus procedimientos se pueden llevar a la praxis musical para analizar y hacer una analogía.

\footnotetext{
${ }^{17}$ Ejemplo: https://www.youtube.com/watch?v=DSeFAKwdsmA Kyrie de la missa L'homme arme (arreglo de Josquin Des Prez)

${ }^{18}$ Ejemplo: https://www.youtube.com/watch?v=mPhWDKT2gSk Madrigal Hor che 'l ciel e la terra. (Claudio Monteverdi)

${ }^{19}$ Ejemplo: https://www.youtube.com/watch?v=pssZnVi h2I Suite Española Op. 47 (Isaac Albéniz)

${ }^{20}$ Ejemplo: https://www.youtube.com/watch?v=JcaNYY0SIOI Variaciones sobre un tema de Haydn Op. 56a (Johannes Brahms)
} 


\section{CAPITULO III}

\section{METODOLOGÍA}

\subsection{Universo y Unidad de Análisis}

La investigación se realizó sobre la propuesta estética y musical del violinista venezolano Alexis Cárdenas y sus procesos de renovación e hibridación de músicas latinoamericanas con música europea.

Las herramientas metodológicas se diseñaron con dos enfoques.

En primer lugar, se seleccionaron dos tracks de la producción discográfica Bicho y hecho (2001) del Ensamble Recoveco, para hacerles un análisis amplio que abarcó diferentes aspectos. De un lado, en cuanto a lo musical, se consideraron los elementos técnicos, rítmicos, melódicos, armónicos, formales y de estilo interpretativo de los géneros implicados.

De otro lado, se visibilizaron las formas de producción, la utilización de recursos intertextuales y la asociación con algunas categorías del lenguaje que se integraron perfectamente en el proceso de reinvención musical.

Finalmente, se abordó el análisis de las obras desde el concepto de hibridación y sus estrategias desde la perspectiva cultural y como forma de producción.

En segundo lugar, aunque no menos importante, se entrevistó a Alexis Cárdenas con el fin de conocer los aspectos más relevantes de su actividad musical, cómo es su proceso creativo al componer y hacer estas mezclas, cuáles son sus motivaciones en cuanto a lo musical y lo sociocultural, qué dimensión estética le da a sus producciones, y cómo su vida de migrante ha influenciado en todos estos aspectos. La entrevista se hizo de forma semi estructurada ya que, si 
bien se partió de preguntas concretas ${ }^{21}$ relacionadas con los temas mencionados anteriormente, las respuestas se dieron a modo de relato, apuntando sobre todo a la experiencia subjetiva de Alexis Cárdenas. De ahí que fue una entrevista flexible, íntima y amena pero siempre estuvo guiada por las preguntas para no perder el foco.

Seleccioné para este proyecto al violinista Alexis Cárdenas porque es un artista comprometido con la difusión y exaltación de la música latinoamericana, ha sido un músico arriesgado y transgresor, capaz de redimensionar la música "Académica o Culta Europea” que todavía en pleno siglo XXI sigue siendo considerada como superior en muchos conservatorios e instancias académicas.

El hecho de ser un latinoamericano que migró a Europa le ha permitido conocer los diferentes códigos, técnicas interpretativas y lenguajes musicales (tanto de la música del folclor llanero venezolano como el repertorio europeo para violín) y esto lo ha sabido aprovechar para posicionar a la música latinoamericana en escenarios europeos, no sólo por lo atractivo de su propuesta, sino por su excelente calidad como músico, su virtuosismo con el violín, y su exquisita sensibilidad e imponencia en la interpretación.

\subsection{Criterios de Selección de los Ejemplos Musicales}

Los ejemplos que se seleccionaron para desarrollar en este trabajo fueron el Capriccio $N^{o} 16$ de Nicolo Paganini y el Pajarillo Con Moto y Acelerando (Brahms/Bach/Trad.). Estas piezas se escogieron pues se encontró en ellas de manera muy explícita la utilización de varios rasgos intertextuales que resultaba interesante resaltar y analizar; además de que eran ejemplos con aspectos en común pero a su vez contrastantes entre sí, al igual que el tratamiento que le da Alexis Cárdenas a cada uno de ellos.

\footnotetext{
${ }^{21}$ Se pueden encontrar las preguntas de la entrevista en el anexo de este trabajo.
} 
Algunas de las características que comparten estos temas son la utilización de citas de música del repertorio europeo para violín, el uso del joropo como género para hacer el puente entre la música europea y la música latinoamericana y la instrumentación.

En cuanto a los elementos contrastantes, lo que vemos en el Capriccio de Paganini es la superposición de una cita textual que se inserta en una base de joropo; es decir, un copiar y pegar. En cambio en el Pajarillo hay uso de diferentes citas de la literatura musical europea, que se utilizan pero para hacer un collage.

Analizando el aspecto formal, también encontramos varias diferencias. En el capriccio se hace una doble interpretación, ya que primero se toca la obra original (violín solo) y después se toca con la base de joropo. Esto lo hace un ejemplo muy interesante, ya que se presenta de manera intencional en una misma obra el Hipotexto y el Hipertexto.

Por su parte, lo particular del Pajarillo tiene que ver con la manera de estructurar la pieza y de su tratamiento formal. Es un tema mucho más largo, que tiene una variedad de citas que se enlazan por medio de pasajes improvisados, haciendo de su primera parte una gran cadenza a manera casi de recitativo. Y lo que hace singular esta obra, es como al final todos estos elementos se van transformando y enlazando a lo que será el final de la pieza, la interpretación de un pajarillo venezolano. 


\section{SEGUNDA PARTE}

\section{CAPITULO IV}

\section{CONTEXTO}

Alexis Cárdenas inició sus estudios de violín a la edad de 7 años en su ciudad natal, Maracaibo, Venezuela, con un maestro argentino que era miembro de la Orquesta Sinfónica de la ciudad y que además tocaba en un mariachi. Paralelo a esto, Alexis hacia música tradicional venezolana con su padre, la cual tocaban en fiestas, parrandas y tertulias.

A los 13 años viajó a los Estados Unidos, donde continuó sus estudios en Nueva York, en la Juilliard School of Music (Pre -College División) con Margaret Pardee y más tarde ingresó al Conservatorio Nacional Superior de Música y Danza de París con Olivier Charlier. Allí se graduó de su clase ganando el primer premio, otorgado por unanimidad.

Para ese momento, su formación a nivel académico siempre se basó en la interpretación de música académica europea ya que el repertorio latinoamericano era impensable en las instituciones de educación musical, más aún en Europa.

A pesar de esto nunca abandonó su gusto por la música popular; por el contrario, siempre de manera paralela se dedicó a ella hasta que decidió ir más allá, proponiendo entrelazar esos dos mundos.

Podemos destacar tres trabajos concretos, como parte de las múltiples influencias que recibió con respecto a la idea de hibridar música académica con música popular. Hace 20 años tuvo la oportunidad de escuchar un proyecto llamado Bach in Brazil (2.000) que combinaba las piezas más conocidas y emblemáticas de Bach con choros brasileños, resaltando lo mejor de ambos lados: por una parte el lenguaje intemporal de Bach, y por otra parte la viveza y la alegría de la 
música brasileña. ${ }^{22}$ De otro lado, conoció el disco Mozart en Egipto (1997) que representa una fusión de la obra de Mozart con los sonidos, ritmos e instrumentos típicos de Egipto y el medio Oriente. $^{23}$

Finalmente, tuvo acceso a un disco del maestro venezolano Abraham Abreu (clavecinista y especialista en música antigua) que gira en torno a la idea de que Bach hizo un viaje a los llanos venezolanos, así que en esta producción se toman algunas obras (gigas, Suites) para re interpretarlas en formato llanero. (Este disco no salió al mercado)

Vemos entonces cómo Alexis Cárdenas, desde muy pequeño y a pesar de tener una formación académica europea, empieza a generar y a alimentar su creatividad y curiosidad por otras músicas, logrando actualmente moverse por los dos mundos y lenguajes no de manera separada o alternada, sino integrada en una nueva forma de re leer y re interpretar.

\subsection{Desarrollo y análisis musical de los temas seleccionados}

En este capítulo haré un análisis de los procesos de renovación, re-significación y recontextualización presentes en la obra del violinista Alexis Cárdenas, tomando como tópico de trabajo los recursos intertextuales y las prácticas apropiacionistas que él utiliza y cómo, a través de estos, logra integrar música europea (para violín) con ritmos tradicionales de músicas latinoamericanas. Para esto mostraré cómo se cruzan algunas categorías del lenguaje literario analizando dos ejemplos musicales donde se puede ver el uso de procedimientos como la cita y el collage. Además, se presentará el análisis musical que aborda aspectos técnicos, rítmicos, melódicos, armónicos y formales.

${ }^{22}$ https://www.muscaria.com/bach_br.htm

${ }^{23} \underline{\mathrm{https}: / / \mathrm{www} . \text { youtube.com/watch? } \mathrm{v}=\mathrm{L} 1 \mathrm{co} 2 \mathrm{r} 0 \mathrm{zMRk}}$ 
También veremos cómo utiliza la Hibridación y sus estrategias como forma de producción y que técnicas y recursos adopta para llevar a cabo este proceso. Además, en qué tipo de categoría podemos localizar su obra.

Para esto, he seleccionado dos temas concretos de su producción musical de 2001 BICHO $\mathbf{Y}$ HECHO, la cual realizó con uno de sus proyectos musicales llamado RECOVECO.

Esta agrupación, cuyo formato musical es de instrumentos de cuerdas del folclor de la música llanera colombo-venezolana (cuatro, guitarrón, guitarra, percusión) más el violín, tiene un amplio repertorio instrumental y vocal de música tradicional que ellos mismos denominan "evolutiva".

Para ellos este término hace referencia a la música que no se queda inmóvil en el tiempo, por el contrario, es la música que se re-significa integrando ritmos y géneros de sus diferentes pasados y antecedentes musicales, con su esencia latina y siempre de la mano de la improvisación. 


\subsubsection{Capriccio $N^{o} 16$ de Nicolo Paganini ${ }^{24}$}

Este tema resulta de la integración de un capricho para violín solo de Paganini (uno de los violinistas Italianos más importantes del siglo XVIII) con la base rítmica y armónica de uno de los géneros más tradicionales de la música venezolana. Como se explicará a continuación, el capricho se renueva y re contextualiza de una forma muy original al citarse textual sobre un fondo (background) de joropo llanero.

El término capricho surgió en Europa y comenzó a utilizarse en el siglo XVI para denominar una pieza musical cuya característica más importante era la libertad en la forma y su carácter vivo y animado. Es una forma predominantemente instrumental, de naturaleza rápida y virtuosa.

Por su parte, el joropo llanero es un tipo de música folclórica (Colombo-Venezolana) de carácter alegre, con acentos marcados y rica en cambios armónicos e improvisaciones.

Surge a partir del siglo XVIII como fiesta popular, donde interviene un instrumento melódico como el arpa o la bandola, acompañado por el cuatro, un par de maracas, canto y baile.

Los géneros del Joropo Llanero se diferencian entre si principalmente por la velocidad de la pieza, la progresión armónica y la métrica.

En cuanto a la velocidad, podemos diferenciar dos grupos que son: el golpe ${ }^{25}$ y el pasaje. ${ }^{26}$

Existen aproximadamente 22 tipos de joropo llanero (en modo mayor o menor) dentro de los cuales podemos destacar: Seis por corrido, Seis numerao, Seis por derecho, Pajarillo, Catira, San Rafael, Guacharaca, Zumba que zumba y Gabán, entre otros. La diferencia entre ellos la determina su progresión armónica (que se repite hasta el final), donde los versos del cantante y el contenido musical son improvisados dentro de este esquema armónico establecido.

\footnotetext{
${ }^{24}$ Esta pieza se encuentra en el track 10 de la producción y se puede escuchar en el siguiente enlace. https://www.youtube.com/watch?v=q2-1uC4DRgg

${ }^{25} \mathrm{El}$ golpe es una variante de tempo rápido, extrovertido, de carácter recio y frases melódicas generalmente breves. ${ }^{26}$ El pasaje se ejecuta en un tempo un poco más lento y es de carácter más lírico, introspectivo, romántico y suave, con frases melódicas más desplegadas.
} 
La parte armónica es ejecutada por el cuatro, ya que sus cuerdas (La-Re-Fa\#-Si) suenan en forma simultánea debido al uso de la técnica del rasgueo.

Con esta técnica se pueden producir dos tipos de sonido: rasgueo abierto (las cuerdas vibran libremente) y rasgueo trancado o chasquido (la mano apaga las cuerdas inmediatamente después de hacerlas sonar). Este último golpe, que es de carácter seco y percusivo, sirve para dar y subrayar los acentos rítmicos del joropo.

En cuanto al aspecto rítmico, el joropo llanero se puede interpretar tanto en una métrica de 3/4 (para todos los pasajes y los golpes corridos) como en una métrica de 6/8 (un pequeño grupo de golpes, el seis por derecho, el seis numerado y el pajarillo). La diferencia entre el grupo del tres (3/4) y el grupo del seis (6/8) radica fundamentalmente en la acentuación.

Cuando se utiliza la métrica de 3/4, el rasgueo trancao o chasquido se hace en la tercera y en la sexta corchea.

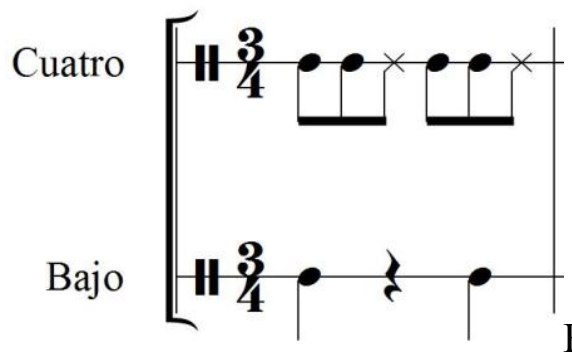

Fig. 1

Cuando se utiliza la métrica de 6/8, el rasgueo trancao o chasquido se hace en la primera y en la cuarta corchea.

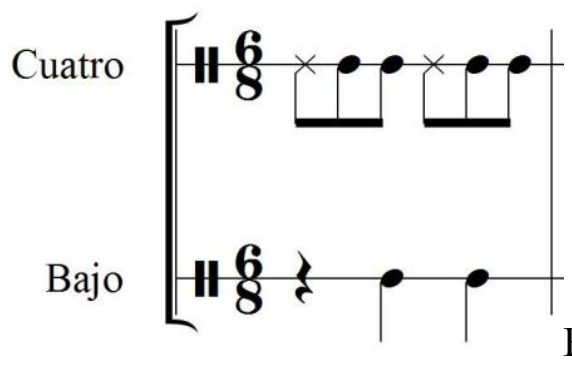

Fig. 2 
Ahora bien, después de conocer algunos aspectos generales tanto del género del capricho como del joropo, vamos a centrarnos en la pieza que es objeto de nuestro análisis, para conocer cómo está concebida e interpretada.

La estructura de la pieza tiene dos partes: en la primera parte se hace la exposición del capricho en su versión original ${ }^{27}$ (para violín solo), a manera de presentación, y en la segunda parte se vuelve a interpretar pero con el acompañamiento instrumental. Es decir que Alexis utiliza un procedimiento de montaje y edición en el cual se copia y se pega una pieza textual y se "cita" dentro de otra totalmente diferente cambiando por completo su significado, con lo que se consigue una hibridación de estilos, culturas y géneros.

\section{Primera parte:}

El capricho $\mathrm{N}^{\circ} 16$ se trata básicamente de un moto perpetuo en semicorcheas que se interpreta a gran velocidad y con golpe de arco detaché, cuya mayor dificultad radica en la rápida alternancia entre cuerdas y en los acentos irregulares que dan la sensación de estar un poco a destiempo. Está escrito en la tonalidad de Sol menor, en una métrica de 3/4 y en textura monofónica. $^{28}$

\footnotetext{
${ }^{27}$ Fig.3. Primera parte. Desde el inicio hasta el 1'23s

${ }^{28}$ Una sola línea melódica sin acompañamiento.
} 
Violin

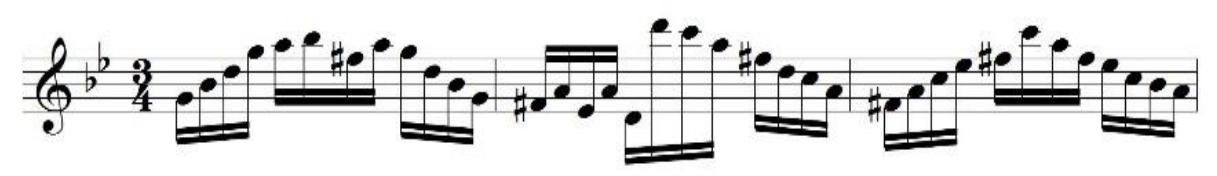

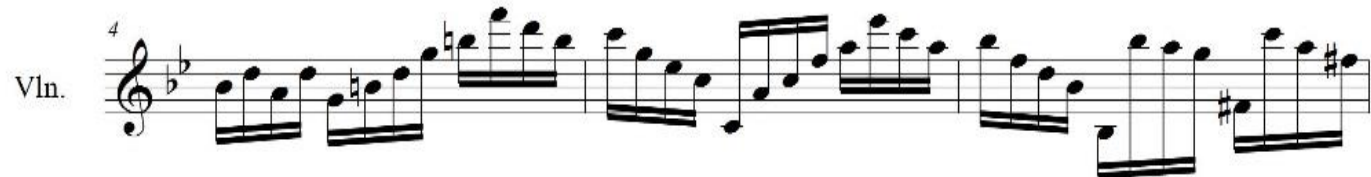
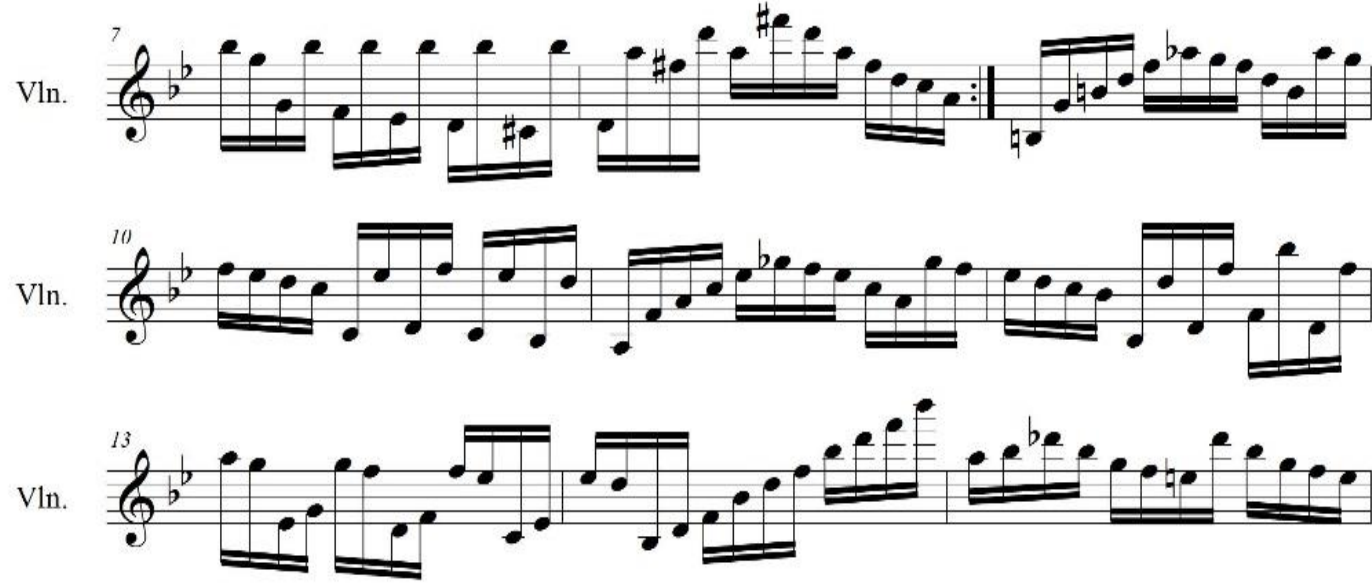

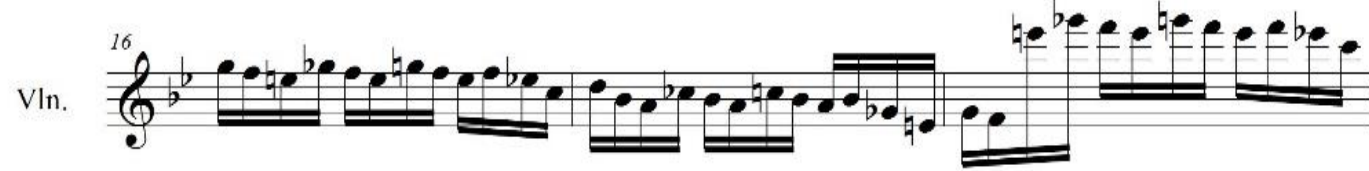

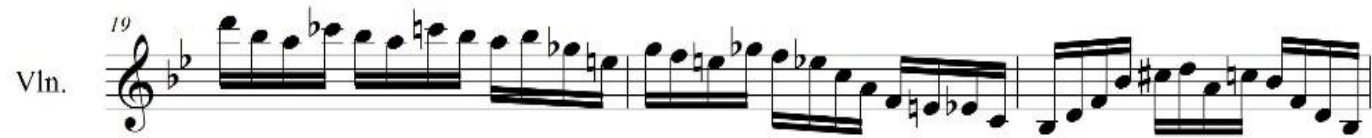

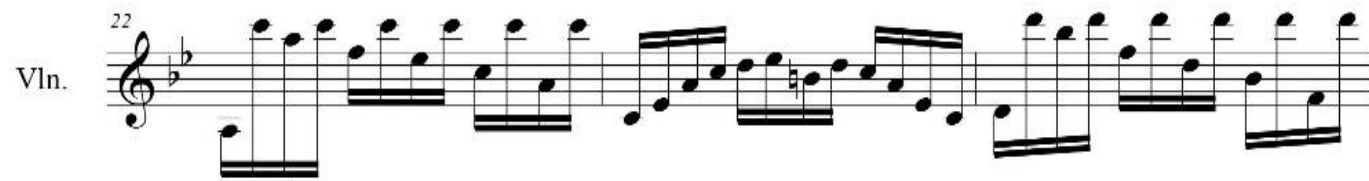




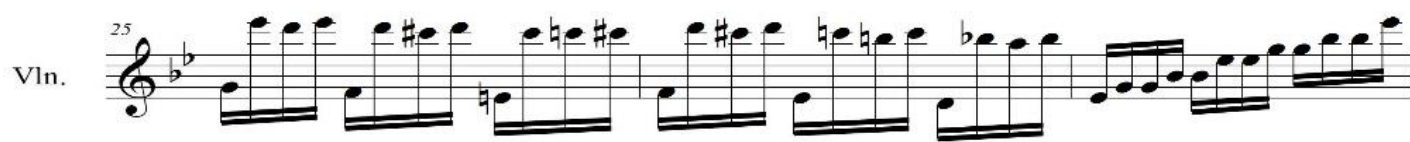

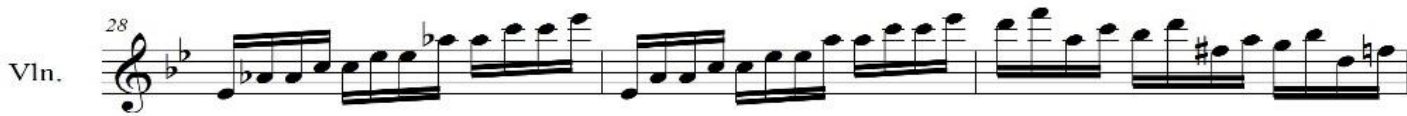

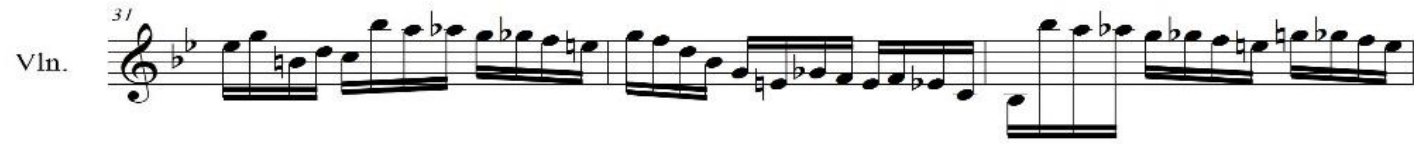

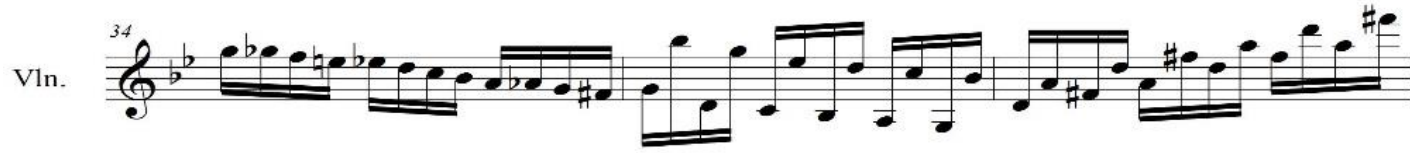

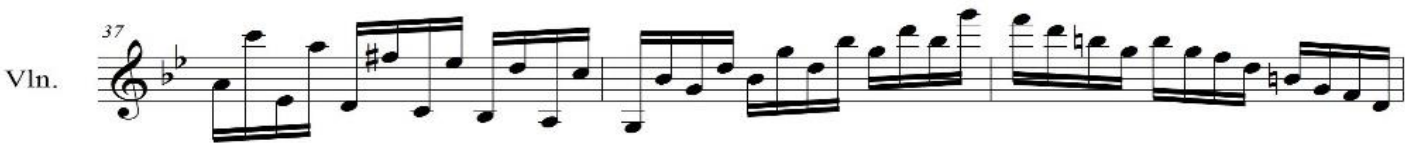

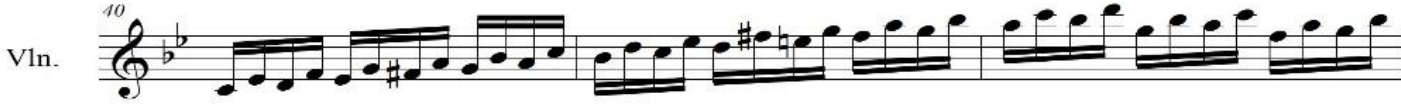

VIn. $\mathrm{g}_{b}^{3}$

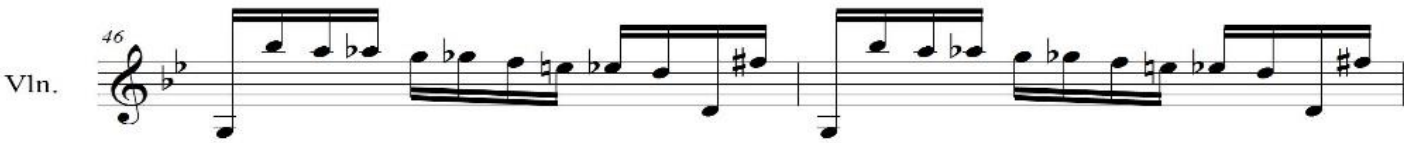

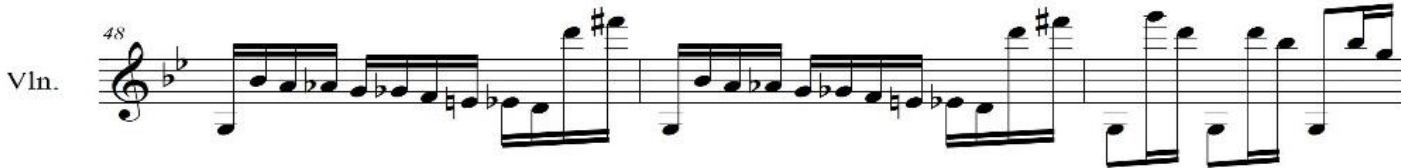

Vln.

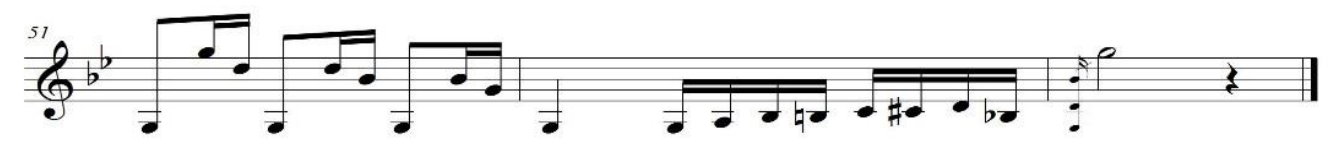

Fig. 3 


\section{Segunda parte:}

El instrumento melódico es el violín y el cuatro es el encargado de hacer la parte armónica.

De este modo, vemos que la textura de la pieza pasa de ser monofónica a transformarse en una melodía con acompañamiento. ${ }^{29}$

Esta sección comienza con un solo de cuatro ${ }^{30}$ que se utiliza a manera de puente para conectar la primera y la segunda parte; y también es a su vez una introducción al joropo que sonará por el resto de la pieza.

El cuatro termina suspendido en una semicadencia en la dominante, con el giro armónico:

\section{ii semi dism- V- V- i- ii semi dism- V-V}

\section{Puente/Intro}

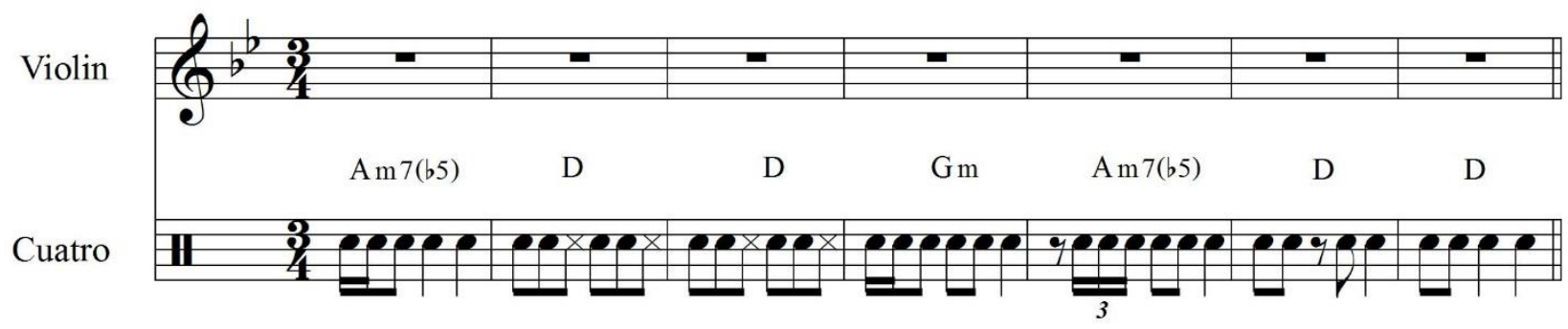

Fig. 4

Después de este puente se volverá a presentar el capricho (como en la primera parte) pero ahora si con el acompañamiento armónico del cuatro. La tonalidad y la métrica se mantienen iguales así que como estamos en 3/4, el chasquido del cuatro será en la tercera y en la sexta corchea. (Ver Fig. 1)

La primera sección de la segunda parte $(\mathrm{A})^{31}$ se repite y es la presentación del tema principal.

\footnotetext{
${ }^{29}$ Una línea melódica principal con acompañamiento rítmico y armónico (instrumental o vocal)

${ }^{30}$ Fig. 4. Segunda parte. Puente/Intro, compases 1 al 7. Del 1'24s al 1'29s.

${ }^{31}$ Fig.5. Segunda parte. Sección (A), compases 8 al 23. Del 1'30s al 1'53s.
} 
En cuanto a la armonía, tenemos una progresión que utiliza los acordes de tónica, dominante, segundo semi disminuido y algunas dominante secundarias, finalizando con una semicadencia en la dominante.

Si comparamos la Fig. 3 con la Fig. 5, lo que vamos a encontrar es la misma melodía en la línea del violín, solo que en la Fig. 5 está aumentada la duración de las figuras rítmicas exactamente al doble. Las semicorcheas pasaron a ser corcheas, lo que implica que en la segunda parte va a haber el doble de número de compases.

Esto sucede porque el patrón rítmico del cuatro siempre se escribe en corcheas, entonces la línea del violín se acomodó para que en las dos voces se conserve la proporción del ritmo. En la velocidad de ejecución de las dos partes se da una variación mínima, siendo la primera un poco más rápida que la segunda.

(A)

Vln.

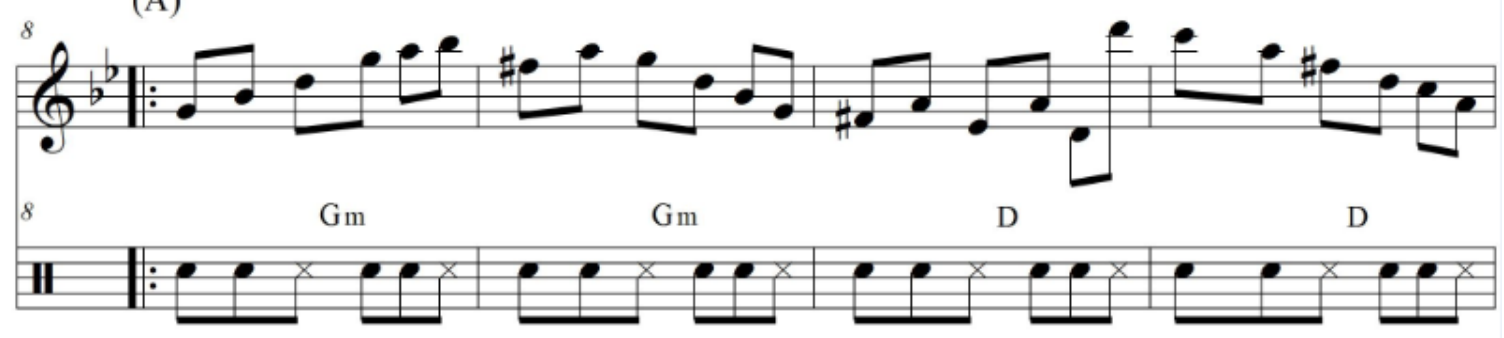

Cuatro

Vln.

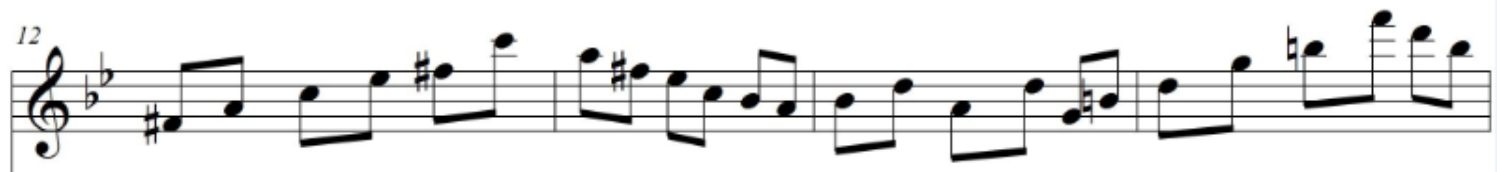

Cuatro

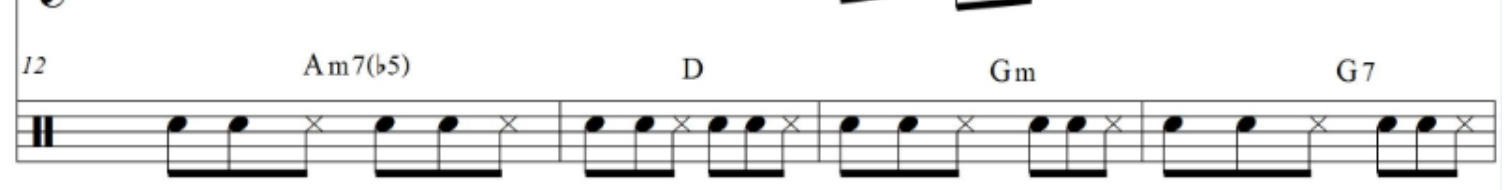



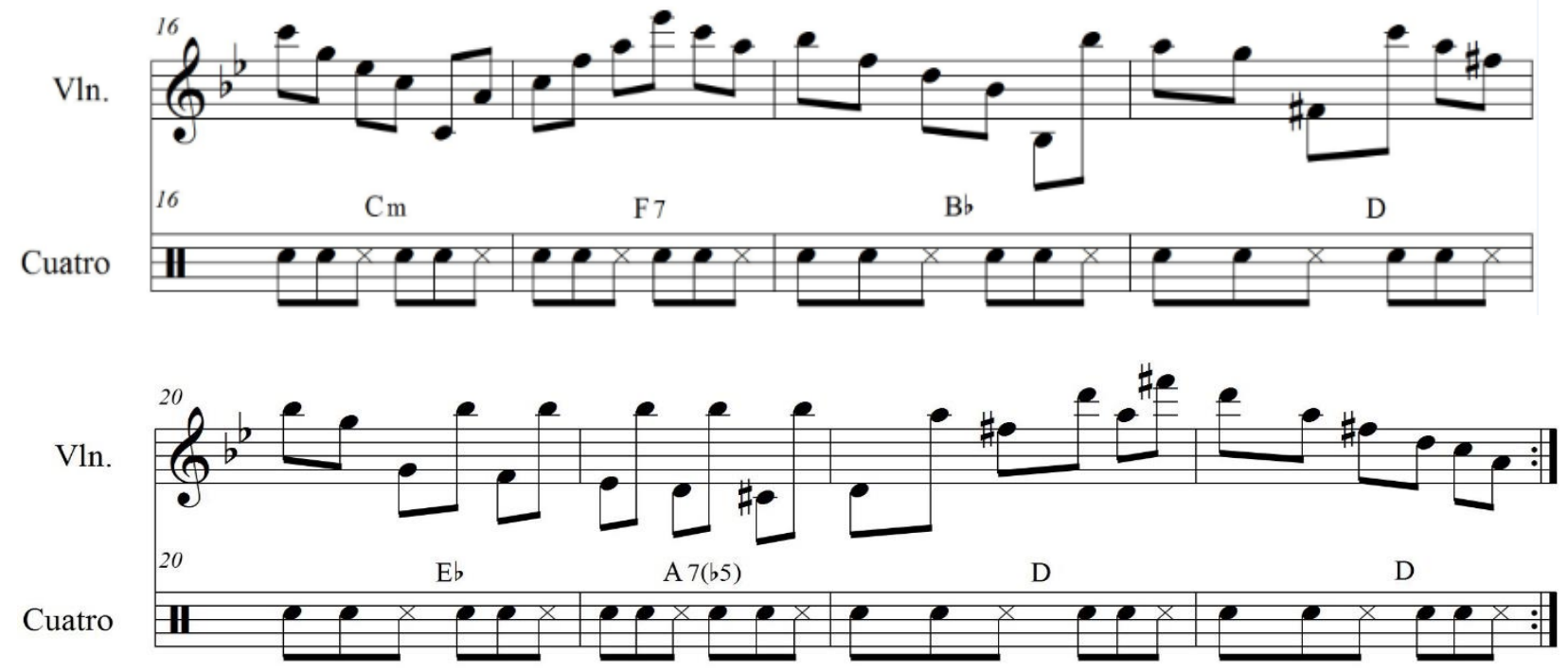

Fig. 5

La siguiente sección, denominada (B), ${ }^{32}$ muestra un fragmento del desarrollo del capricho.

En el compás 27 el acorde de Cm se convierte en el acorde pivote para modular a Bb Mayor; es decir, a la relativa mayor de la tonalidad inicial.

Cm: pasa de ser la subdominante (iv) de Gm y se convierte en el segundo grado (ii) de BbM

Al ser una modulación pasajera, en la partitura se ve el cifrado con respecto a la tonalidad de Gm, sin embargo hay que tener en cuenta que función cumplen esos acordes en la tonalidad relativa.

Cifrado de los compases 28 al 35 con respecto a la relativa mayor (BbM):

$$
\text { V7- V7- I- I- (IV, I) - (I, V) - I- I- Etc... }
$$

\footnotetext{
${ }^{32}$ Fig.6. Segunda parte. Sección (B), compases 24 al 47. Del 1’53s al 2’10s.
} 

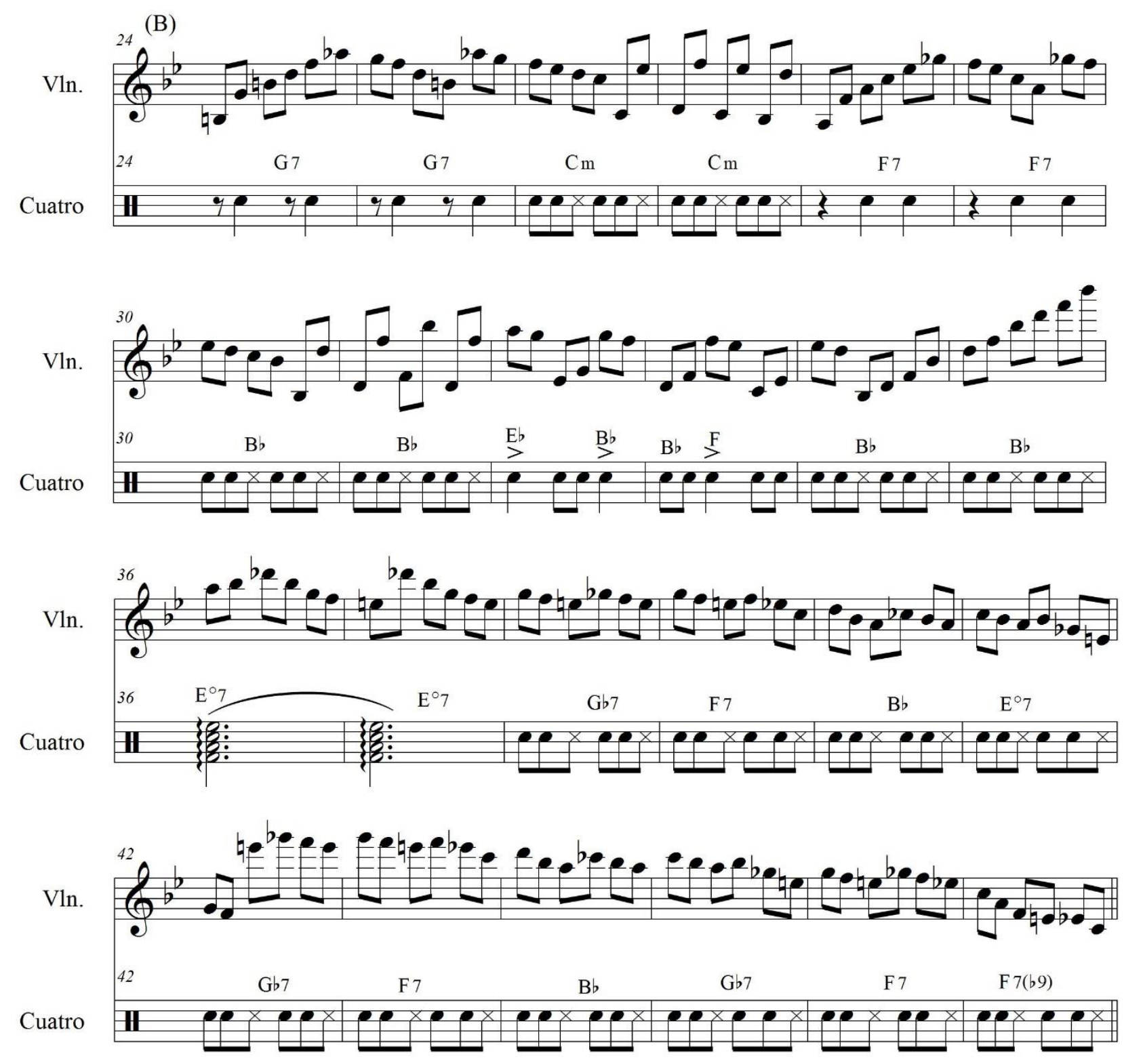

Fig. 6

Por último, tenemos la sección final de la segunda parte $(C)^{33}$ que por medio de una secuencia de terceras del violín solo (primero ascendentes y luego descendentes) nos acerca a lo que será el final del capricho.

La progresión armónica del cuatro para esta sección final (compás 77 al 94) se repite varias veces y es:

${ }^{33}$ Fig. 7. Segunda parte. Sección (C), compases 67 al 94. Del 2’39s al 3’20s. 


\section{ii semi dism- V- i}

El segundo grado claramente tiene aquí función de subdominante, por lo cual la progresión es una cadencia del tipo iv-V-i.

La cadencia final no es completa ni perfecta (que sería lo tradicional si pensamos en el acorde final del capricho), porque el cuatro le agrega al acorde de Gm la sexta, lo cual le da un color muy distinto y una sensación de suspensión.
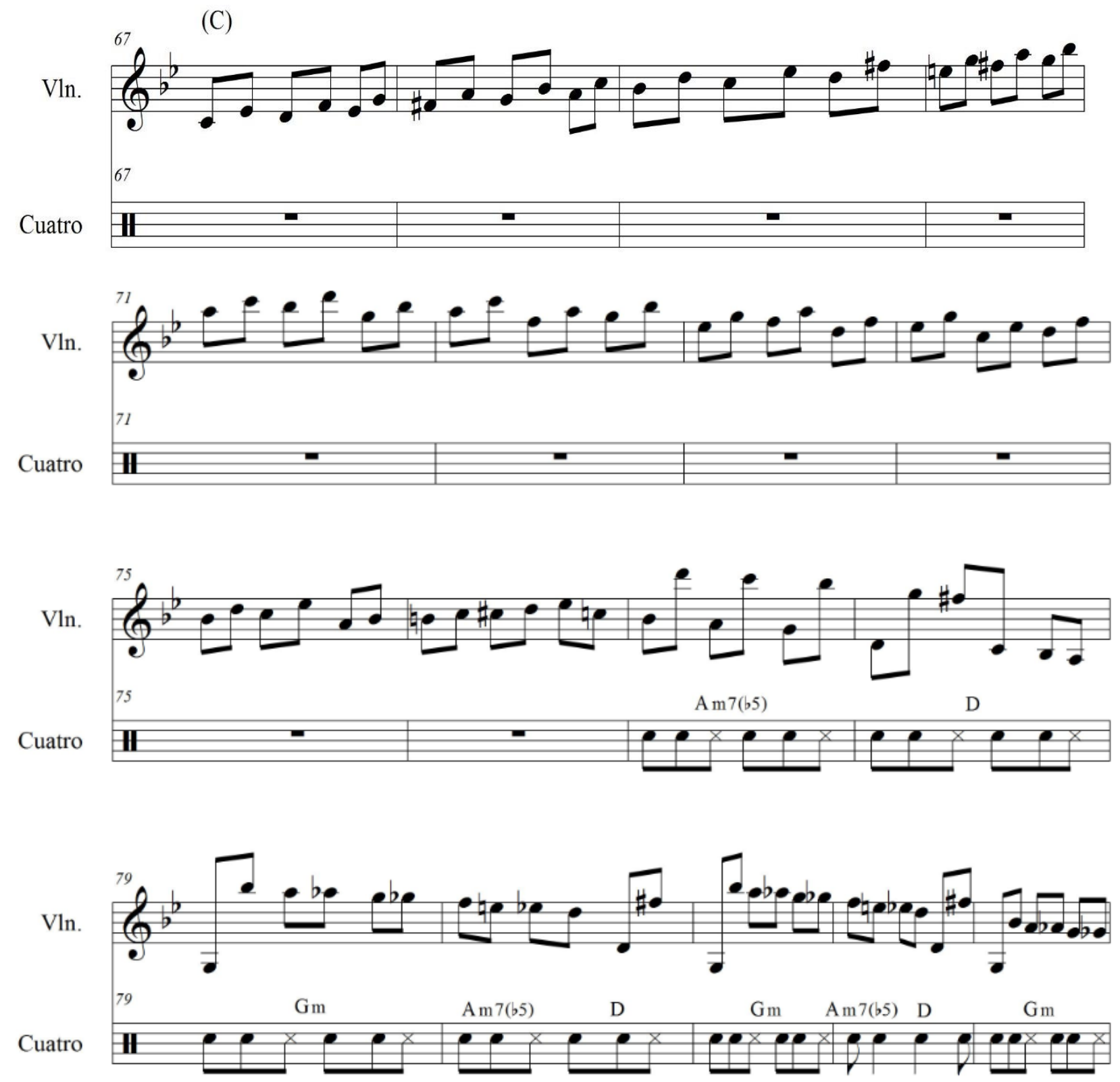

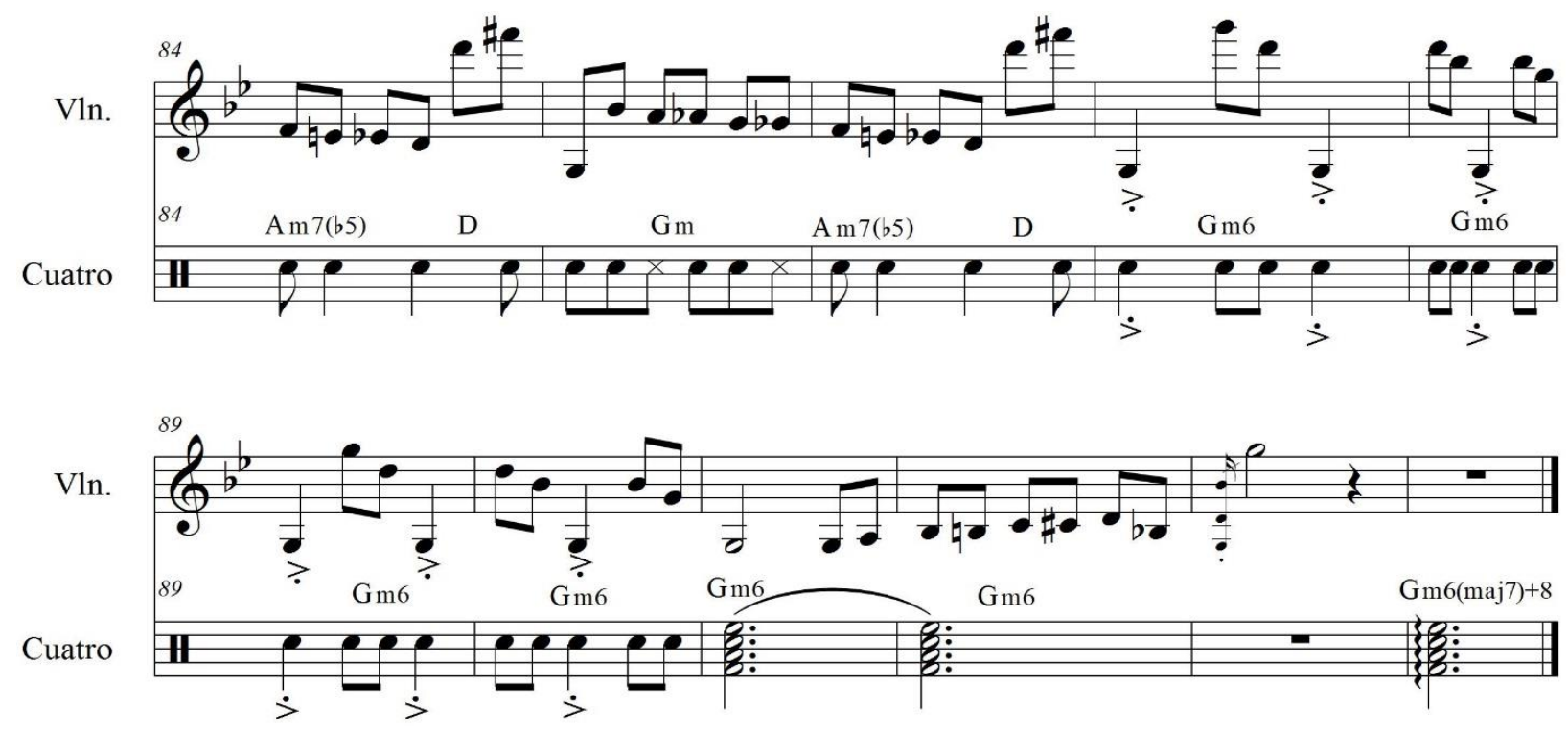

Fig. 7

Si observamos los compases 87 al 90 (Fig.7), vemos cómo tanto en la línea del violín como en la línea del cuatro, la parte rítmica cambia y se marcan unos acentos determinados (o explícitos) que no corresponden a la manera habitual de acentuar el compás de 3/4 (donde sólo se acentúa el primer tiempo o tiempo fuerte).

Esto se conoce como Hemiola y aquí el acento no se marca cada tres tiempos sino cada dos, dando la sensación de que se ha cambiado a una métrica binaria. Además, hay que destacar que este énfasis se hace siempre sobre la tónica para reafirmar la sensación de conclusión o final.

Para Alexis Cárdenas, la idea de hacer una nueva versión del capricho surgió a partir de la necesidad de divertirse tocando a Paganini, cuyo repertorio virtuoso y de gran exigencia técnica siempre ha sido el sufrimiento de los violinistas. Él decide imprimir el elemento lúdico y combinarlo con música llanera, ya que los acentos que se plantean en este capricho son muy similares a los de una línea de bajo de joropo. ${ }^{34}$

\footnotetext{
${ }^{34}$ Entrevista a Alexis Cárdenas.
} 
De otro lado, si examinamos el ejemplo desde el análisis literario podemos retomar el concepto de Transtextualidad de Gerard Genette (1989). Vemos entonces que Alexis Cárdenas utiliza como recursos la Intertextualidad y la Hipertextualidad. La primera se hace visible al utilizar la cita (capricho) para copiarla y pegarla sobre el joropo. Él se vale de dos o más textos dentro de su discurso musical y al superponerlos genera un texto nuevo.

La hipertextualidad se manifiesta de la siguiente manera. El hipotexto es el capricho de Paganini original y el hipertexto es la forma final; es decir, la resultante del montaje del capricho en el joropo. Es curiosa la complejidad de este ejemplo porque acá se nos presenta en la misma pieza tanto el hipotexto como el hipertexto, así que el espectador u oyente puede percibir de forma explícita como se realiza el montaje. Intencionalmente se nota el antes y el después. 


\subsubsection{Pajarillo Con Moto y Acelerando (Brahms/Bach/Trad.) $)^{35}$}

Esta pieza es bastante extensa y está dividida en tres partes:

La primera parte se construye a partir de la yuxtaposición de diferentes citas de música académica (del repertorio para violín) que se interpretan a manera de $\mathrm{Cadenza}^{36}$, la segunda parte es una sección donde se introduce poco a poco el aire llanero y el cuatro hace un solo protagónico, para finalmente desembocar en la tercera parte donde se interpreta el Pajarillo.

\section{Primera parte:}

Se divide en dos secciones. La primera denominada $(\mathrm{A})^{37}$ empieza citando la entrada del violín solista del primer movimiento del concierto para violín y orquesta en Re Mayor op. 77 de Johannes Brahms ${ }^{38}$ (que si bien es cierto está escrito en tonalidad mayor, inicia en la paralela menor).

Alexis Cárdenas va haciendo una transformación por medio de su habilidad para improvisar y de moverse por el plan armónico sobre el cual va a girar la pieza; es decir, la tonalidad de Re Menor. Así, partiendo de esta cita, y después de realizar una serie de secuencias para conectar con la segunda sección $(\mathrm{B})^{39}$ presenta un fragmento de la Chacona de la segunda Partita para violín solo en Re menor de Juan Sebastian Bach ${ }^{40}$.

\footnotetext{
35 Esta pieza se encuentra en el track 12 de la producción y Se puede escuchar en el siguiente enlace. https://www.youtube.com/watch?v=P7tLCJLSvZI

${ }^{36}$ Una Cadenza es un pasaje ornamental escrito previamente o improvisado, que interpreta un instrumentista o cantante solista. Normalmente se ejecuta con un estilo rítmico libre haciendo además una exhibición de virtuosismo.

${ }^{37}$ Fig. 8. Primera parte. Sección (A), compases 1 al 9. Del inicio al 0’21s.

${ }^{38}$ La cita del concierto de Brahms se da entre el compás 1 y la primera corchea del compás 5.

${ }^{39}$ Fig. 9. Primera parte. Sección (B), compases 15 al 31. Del 0’45s al 1’29s.

${ }^{40}$ La cita de la chacona se da entre el compás 23 y el 27.
} 
Armónicamente, en la sección (A) se expone la tonalidad principal (Re m) utilizando los acordes de tónica, sexto grado y cadencial 6/4. Después, hace una secuencia descendente sobre la escala menor armónica y finalmente se suspende en una semicadencia sobre la dominante.

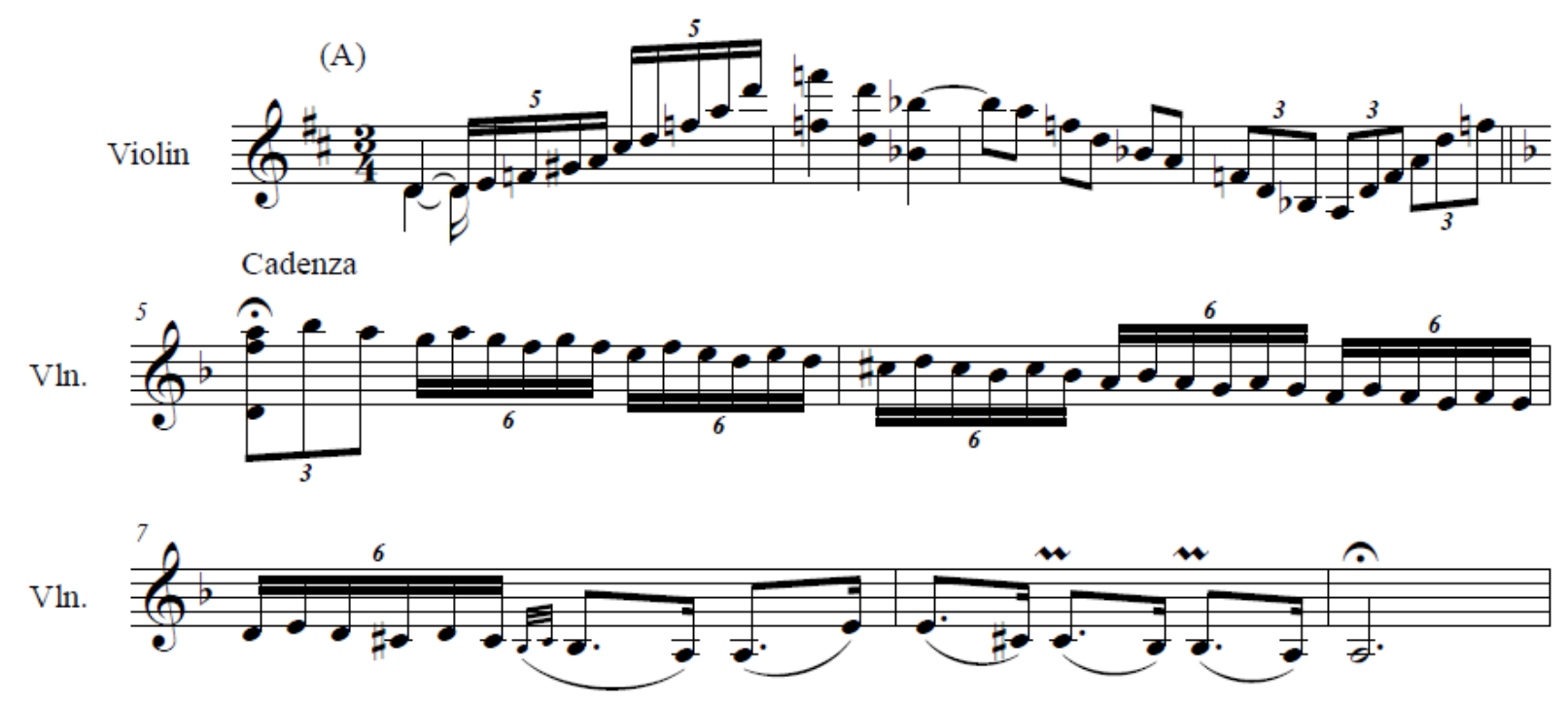

Fig. 8

Empezando la sección (B) la melodía se mueve por las funciones principales de dominante y tónica, luego en el compás 19 y 20 se presenta una secuencia por cuartas que desciende y se utiliza para conectar en el compás 23 con la cita de un fragmento de la Chacona ${ }^{41}$.

Esta sección es contrastante ya que Bach utiliza el violín como instrumento armónico a través de algunos recursos técnicos como las dobles cuerdas y acordes. De otro lado, vemos que se reitera la nota LA (Dominante) en el plano superior, dejando la línea melódica en el bajo. Esto genera una textura contrapuntística que resalta la armonía.

Cifrado de los compases 23 al 27: V - (i, iv) - (V7/III, III) -V7 - V7

\footnotetext{
${ }^{41}$ La chacona es una forma instrumental del siglo XVII, que se define como una variación continua de tempo lento y compás ternario. Está escrita sobre un bajo ostinato.
} 
Finalmente, en los últimos 4 compases de esta sección, Alexis ejecuta un motivo melódico sobre el acorde de dominante que se repite en tesitura de tres octavas y termina suspendido en un trino.

Vln.

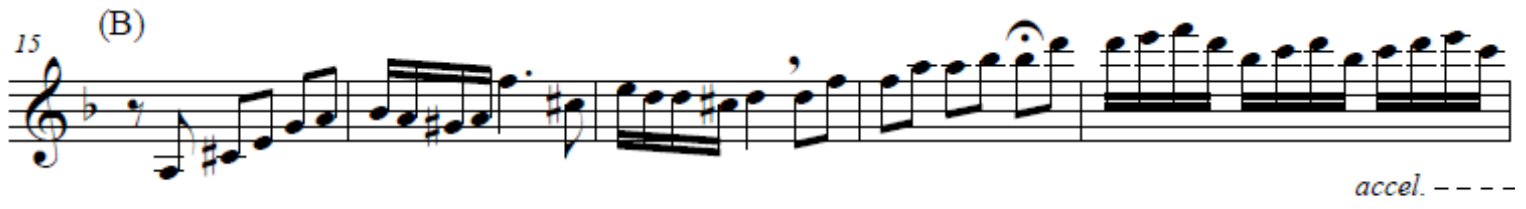

Vln.

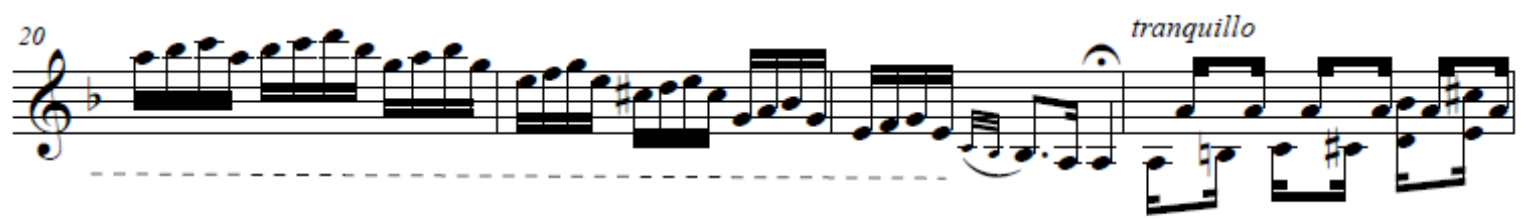

Vln.

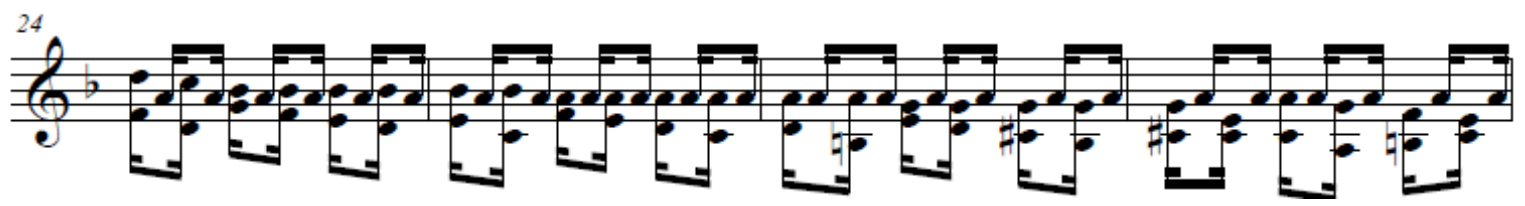

$\operatorname{Vln}$

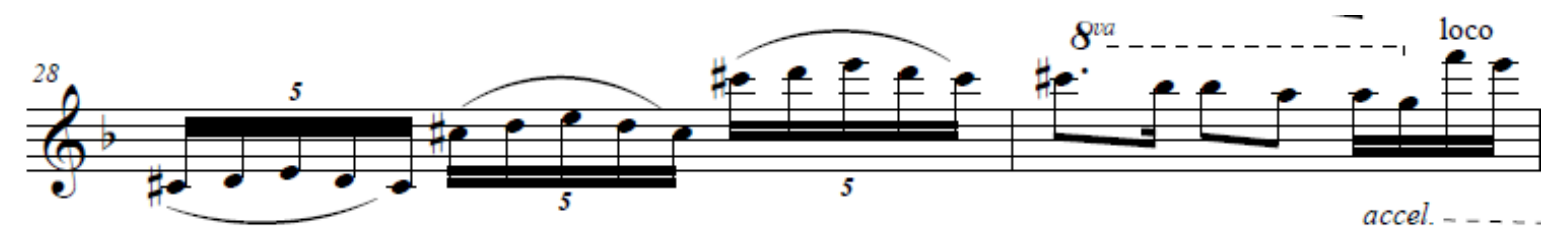

Vln.

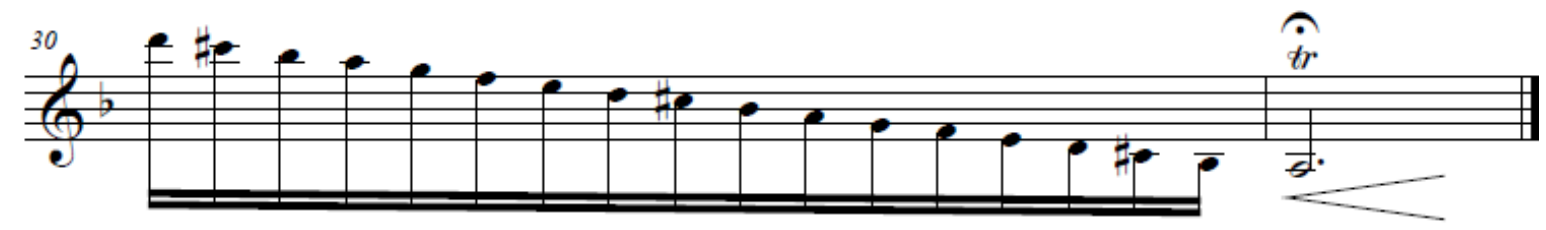

Fig. 9

\section{Segunda parte:}

También está dividida en dos secciones. 
La primera sección $(C)^{42}$ continúa con el violín solo pero es evidente que hay un cambio en el carácter y en el estilo que es muy contrastante con respecto a la primera parte. Las secciones A y B están concebidas a manera de cadenza, así que en ellas percibimos libertad y flexibilidad en el ritmo, la improvisación y la interpretación. Además poseen un carácter melódico y expresivo.

En cambio, vemos que en esta nueva sección el violín transforma ese carácter lírico y nos presenta un patrón rítmico y armónico muy marcado que se convertirá en la antesala del Pajarillo.

Aunque la tonalidad se mantiene, a partir de este momento hay un cambio de métrica ya que pasamos de 3/4 a 6/8. (Recordemos que esta es la métrica en la que se escribe y acentúa el golpe de pajarillo).

Alexis Cárdenas logra este efecto en el violín gracias a su impecable dominio del arco y a la velocidad que imprime para cambiar constantemente entre los golpes de $\operatorname{arco~Spiccato~}^{43} \mathrm{y}$ Ricochet $^{44}$, así que pone al servicio de la música todos los recursos de la técnica violinística para evocar la sonoridad del arpa, la bandola, las maracas y el cuatro que son los instrumentos tradicionales con los que normalmente se interpretan estas secuencias rítmicas y armónicas.

Vemos entonces que Alexis Cárdenas nos está presentando e introduciendo (a manera de alusión) el aire llanero que se va a desarrollar más adelante.

En el plano armónico, esta sección plantea unas progresiones que se repiten o cambian cada 8 compases, salvo la última que dura 11.

\footnotetext{
${ }^{42}$ Fig. 10. Segunda parte. Sección (C). Del 1'29s al 2'17s

${ }^{43}$ Golpe de arco que se realiza en los instrumentos de cuerda frotada. El arco se desplaza por la cuerda y rebota ligeramente haciendo pequeños saltos. (Se ejecuta en la parte media o punto de equilibro del arco)

${ }^{44}$ Es otra variedad de los golpes saltados en el que el arco rebota gracias a la elasticidad natural de la vara. En este golpe se deja caer el arco desde cierta altura dejando que rebote por sí mismo. (Se ejecuta más hacia la punta del arco)
} 
Están conformadas por una variedad de acordes como el de tónica con 9na, el quinto grado menor, el segundo semi disminuido y algunas dominantes secundarias pero siempre en el final de cada una de ellas se va a utilizar el acorde de dominante. (Compases 8, 16, 24, 32 y 43)

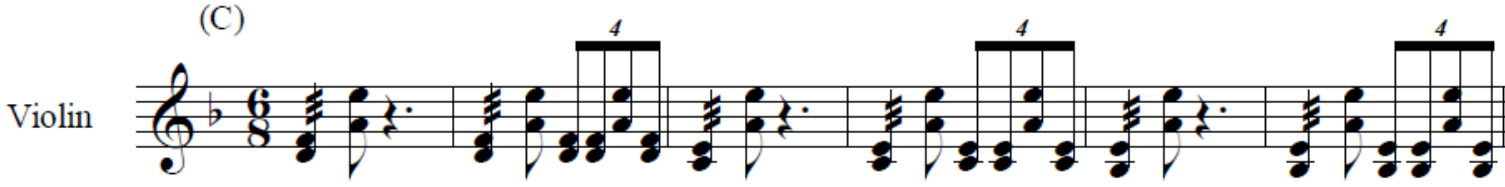

Vln.

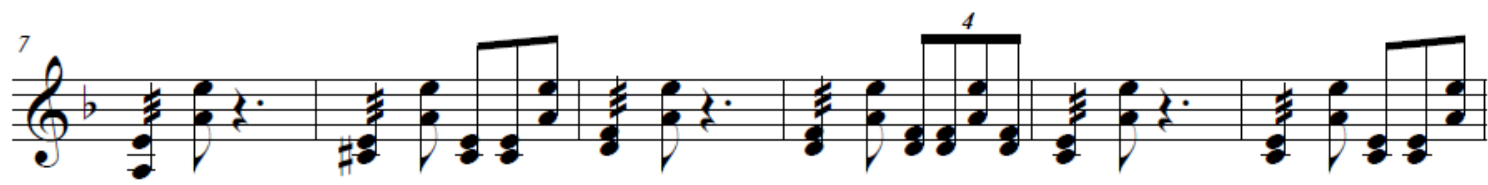

Vln.

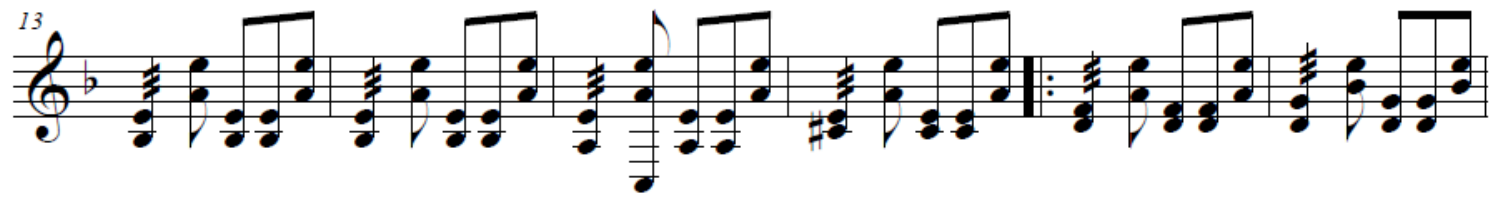

$\mathrm{Vln}$

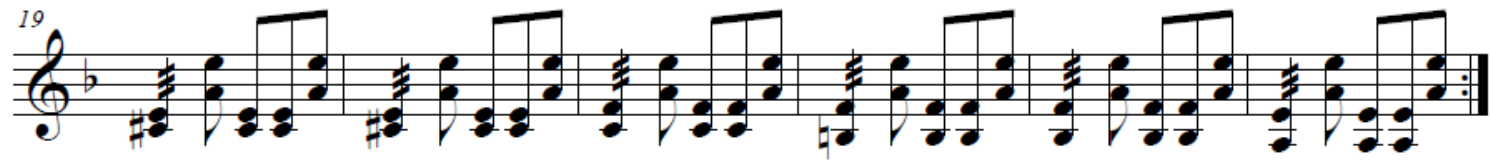

Vln.

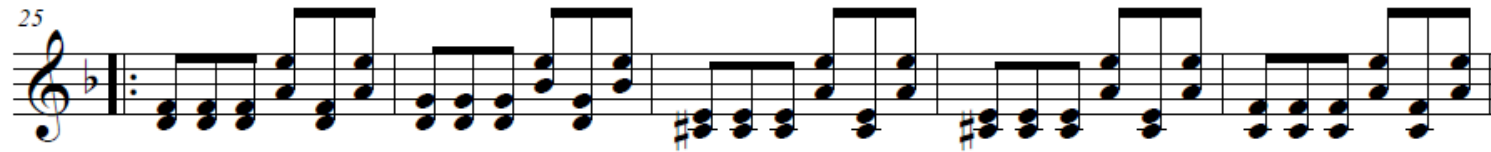

Vln.

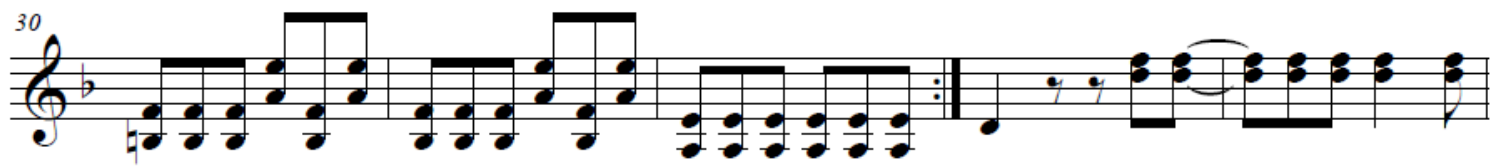

Vin.

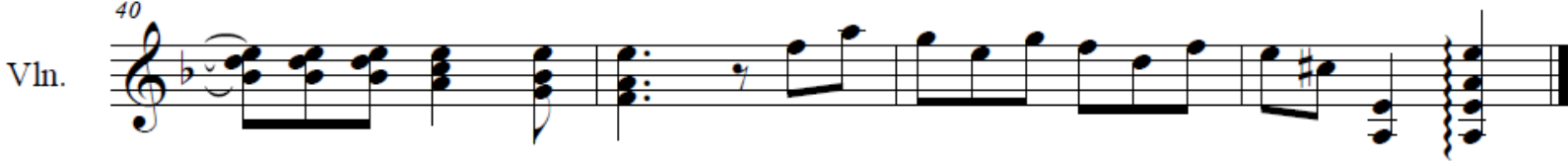

Fig. 10 
En la segunda sección de esta parte (D) ${ }^{45}$, hace su aparición el cuatro (que es interpretado por el músico invitado Cheo Hurtado ${ }^{46}$ ), ejecutando un solo bastante extenso y virtuoso. Es importante mencionar que aunque el cuatro se ha desempeñado en su mayoría como un instrumento de acompañamiento (dentro de los formatos de música llanera), ha ido desarrollando desde hace algunas décadas una estética, una técnica y un estilo interpretativo propio que le ha permitido abrirse un espacio como instrumento protagónico.

En esta sección vamos a escuchar al cuatro interpretando una secuencia melódica, rítmica y armónica muy rica, contrastante y variada, donde se destacan dos aspectos técnicos importantes. De un lado, está la elaboración rítmica de la mano derecha donde se utilizan distintos tipos de repiques o floreos ${ }^{47}$, acentos, golpes y chasquidos. De otro lado, está todo el trabajo de la mano izquierda donde se exploran varias posibilidades de tocar los acordes, de disponer sus notas y de variar sus inversiones $^{48}$, a la vez que se da un movimiento por todas las regiones del diapasón, cambiando de registro, tesitura y por ende de color.

\section{Tercera parte:}

Esta es la última parte (que en duración abarca aproximadamente la mitad de la pieza) y aquí vamos a ver como después de haber hecho un recorrido por diferentes citas musicales, se juntan finalmente el violín y el cuatro para interpretar "El Pajarillo"49.

El pajarillo es uno de los golpes de joropo más comunes de interpretar y se caracteriza por resaltar el virtuosismo de los músicos debido a su velocidad y fogosidad. Alcanza un nivel muy

\footnotetext{
${ }^{45}$ Segunda parte. Sección (D). Del 2'18s al 4'31s

${ }^{46}$ Asdrúbal José Hurtado es un músico y compositor venezolano, considerado precursor de la técnica del cuatro solista y su internacionalización.

${ }^{47}$ Son los ornamentos y variaciones rítmicas de la mano derecha que se utilizan para crear diferentes texturas y efectos en una pieza.

${ }^{48}$ A este estudio se le conoce como Voicings.

${ }^{49}$ Se puede escuchar en el siguiente enlace la versión tradicional y original del pajarillo interpretado por Dennys del Río. https://www.youtube.com/watch?v=iqM-60mGkFc
} 
alto de intensidad musical y tal vez es por esto que resulta ser una de las piezas preferidas por los intérpretes de música llanera. Está escrito en métrica de 6/8 haciendo parte de los golpes del grupo del seis, así que el chasquido del cuatro es en la primera y en la cuarta corchea. (Ver Fig. 2)

Se toca en tonalidad menor y tiene como base la siguiente progresión armónica:

\section{i-iv-V7-V7}

Para analizar el pajarillo voy a seleccionar tres momentos importantes del desarrollo temático.

En la primera sección $(\mathrm{E})^{50}$ vemos que el violín reaparece haciendo una nota sostenida, que luego reitera una octava arriba por los primeros 25 compases. Esto lo hace con el fin de representar el grito sostenido o tañio que hace el cantador en un gesto declamatorio. (Este a su vez, se dice que emite el sonido para evocar los gritos de los vaqueros al reunir o desplazar el ganado). Esta nota usualmente representa el quinto grado de la tonalidad (dominante) y por su carácter y fuerza, anuncia la calidad del solista. También podemos ver que el cuatro poco a poco va a abandonar los repiques solistas con los que venía de la segunda parte para volver al lugar de acompañante por el resto de la pieza.

Ya en el compás 26 empieza a desarrollarse en el violín la melodía principal del pajarillo, quién continua representando la línea que ejecuta el cantante en el formato tradicional.

En el plano armónico vemos que se cumple con la progresión del golpe pajarillo (i-iv-V7-V7) y que se repite durante toda la sección, con la variante de que la subdominante es reemplazada por un acorde de segundo grado semi disminuido con suspensión de cuarta; sin embargo, este acorde mantiene la misma funcionalidad dentro del plan tonal. Hay que destacar que algunos acordes son enriquecidos con la utilización de 9nas, 13vas y que se varían también sus inversiones.

\footnotetext{
${ }^{50}$ Fig. 11. Tercera parte. Sección (E), compases 1 al 65. Del 4’32s al 5’16s
} 
Ya en el compás 51 con levare vemos que Alexis Cárdenas vuelve a la ejecución del patrón rítmico y armónico de corcheas, aquí utiliza dobles cuerdas en secuencias de terceras marcando el carácter recio, fuerte y vivaz que caracteriza este golpe.
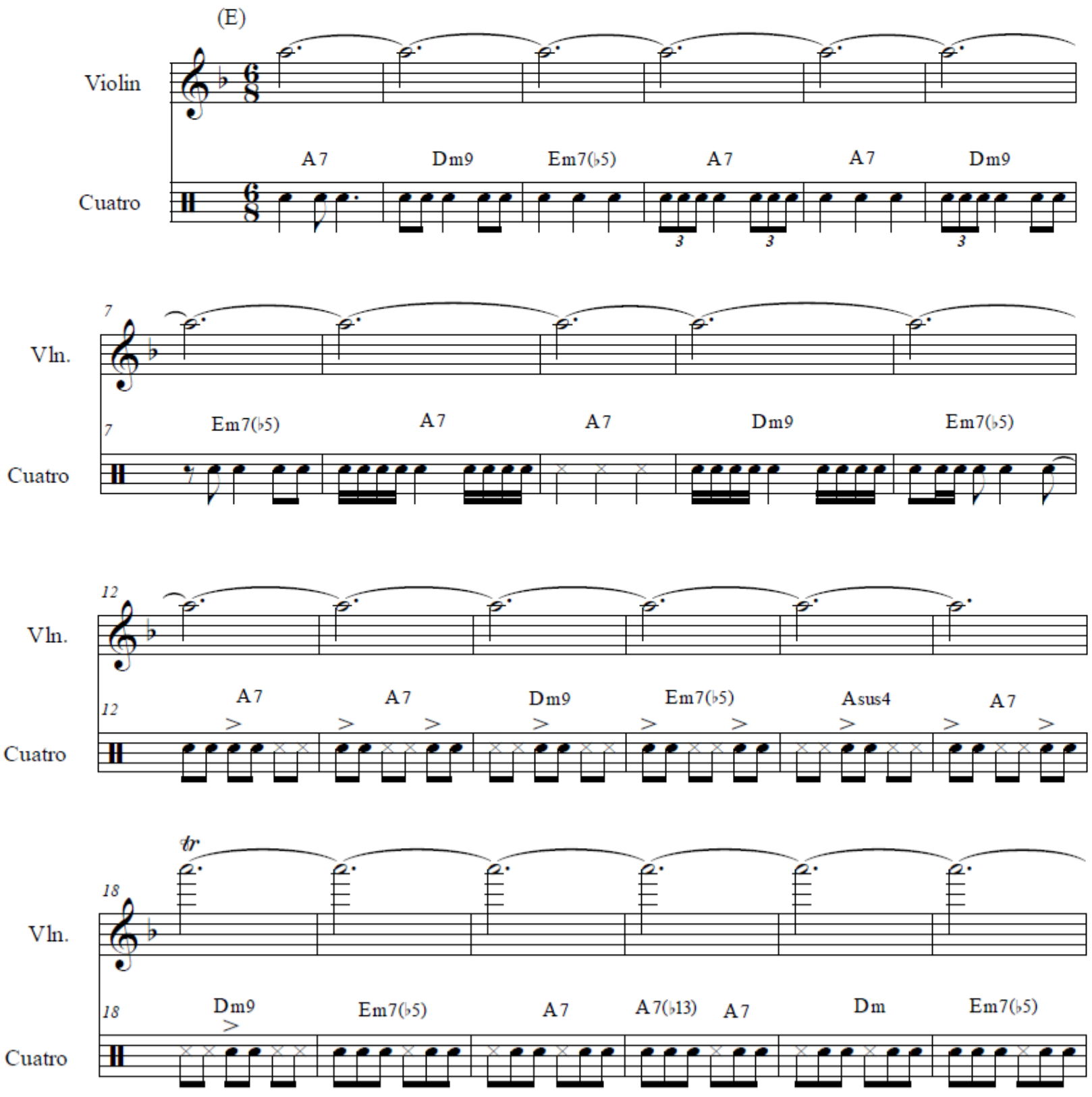
Vln.

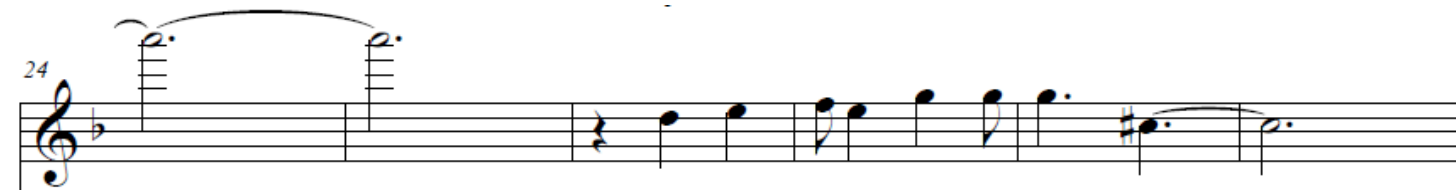

Cuatro

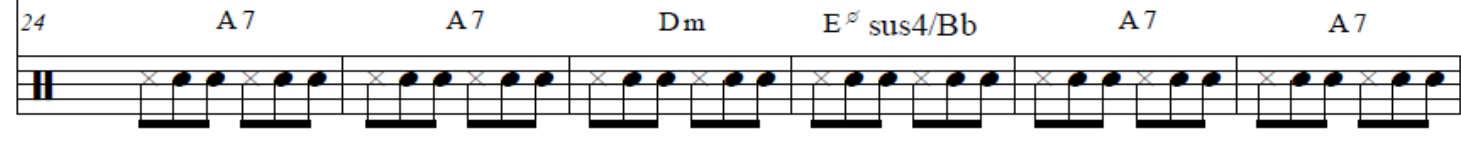

Vln.

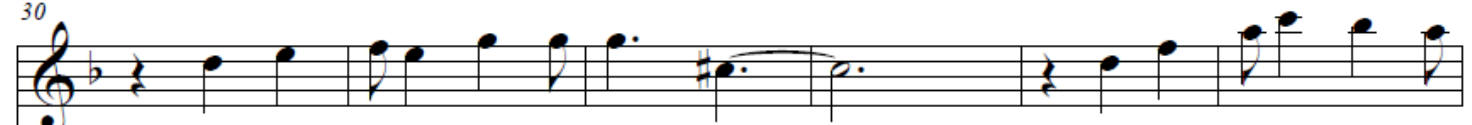

Cuatro

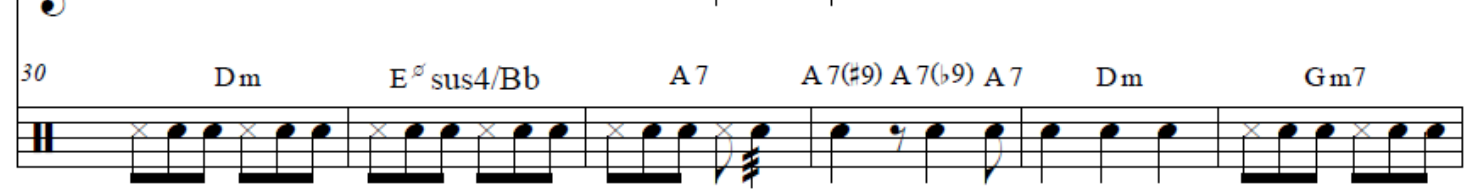

Vln.

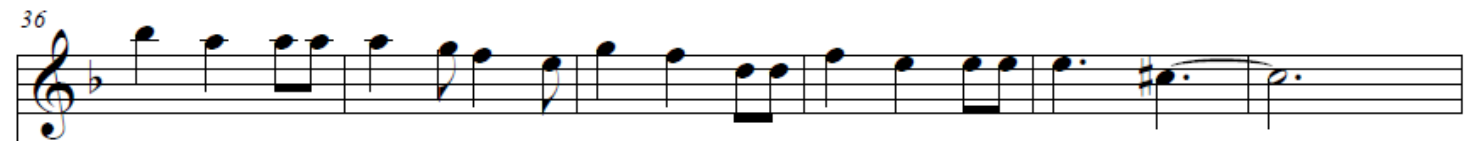

Cuatro

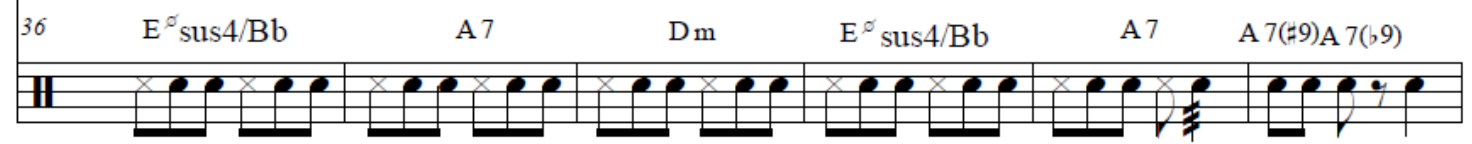

Vln.

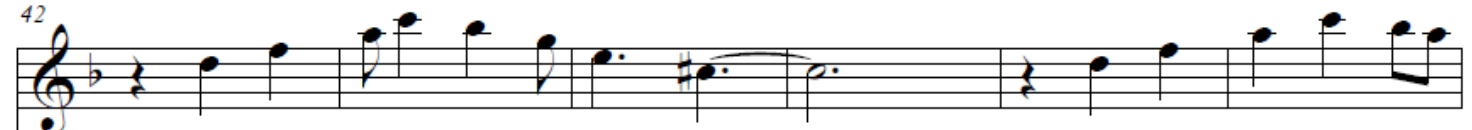

Cuatro

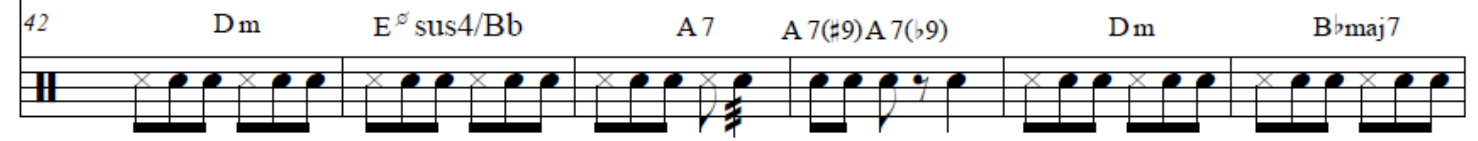

Vln.

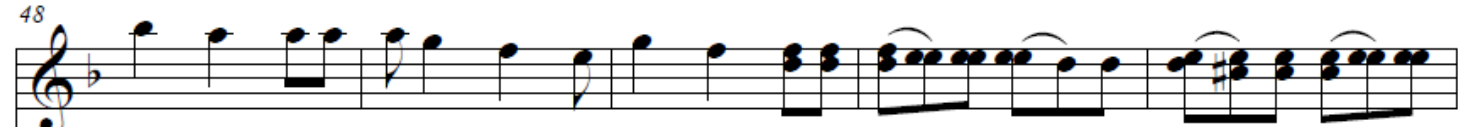

Cuatro
A 7
A 7(b13)/c
D m $7 / \mathrm{c}$
$\mathrm{E}^{\sigma}$ sus $4 / \mathrm{Bb}$
A 7

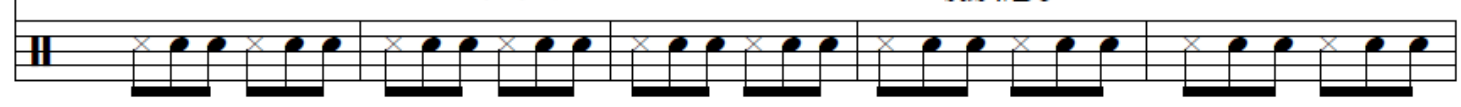



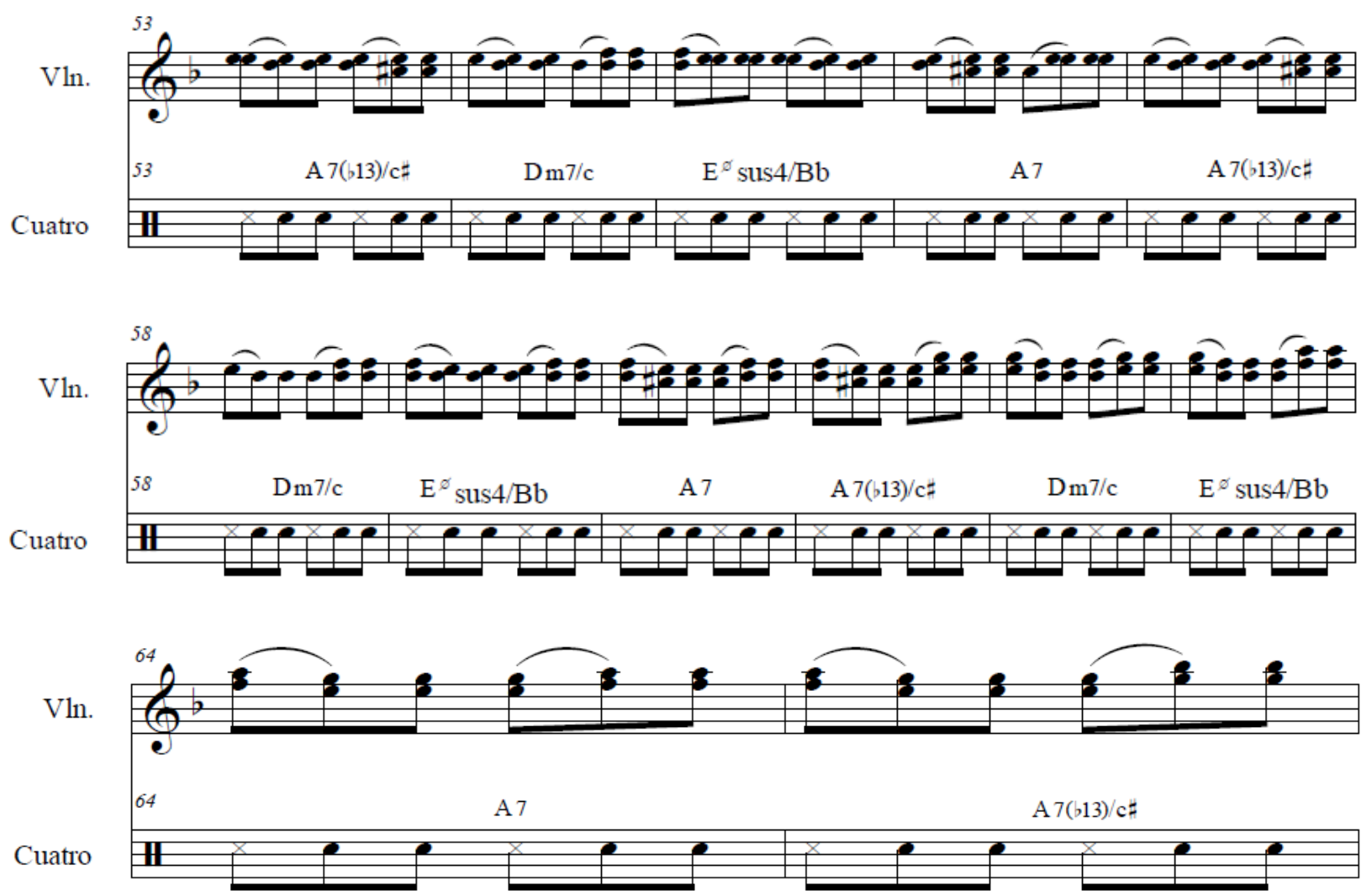

Fig. 11

La segunda sección que veremos $(\mathrm{F})^{51}$ se caracteriza por ser un pasaje cadencial. Y es que aunque no es el final de la pieza, armónica y rítmicamente se genera y se reitera una fuerte tensión en la dominante que pareciera que va a ser resuelta.

Desde el compás 73 y hasta el compás 84 (en grupos de 4 compases) vemos que funcionalmente se hace el siguiente giro armónico:

\section{i- VI maj 7-V7- V7}

Luego, a partir del compás 85 y hasta el 104 (también en grupos de 4 compases) vamos a ver que el giro está formado por una Cadencia Frigia ${ }^{52}$ con la siguiente progresión:

\section{i- V6 menor-ii semi (sus 4) 4/3- V7}

\footnotetext{
${ }^{51}$ Fig. 12. Tercera parte. Sección (F), compases 73 al 104. Del 5’57s al 6’18s

${ }^{52}$ La cadencia frigia es un tipo de semicadencia exclusiva del modo menor. Su nombre deriva del modo griego frigio debido a que poseen la misma estructura en el tetracordio superior descendente. Se caracteriza por finalizar con un intervalo de segunda menor en la voz más grave.
} 
En este tipo de cadencia, se utiliza el tetracordio superior descendente de la escala menor natural y un movimiento en el bajo del tipo:

\section{i-VII-VI-V}

Vln.

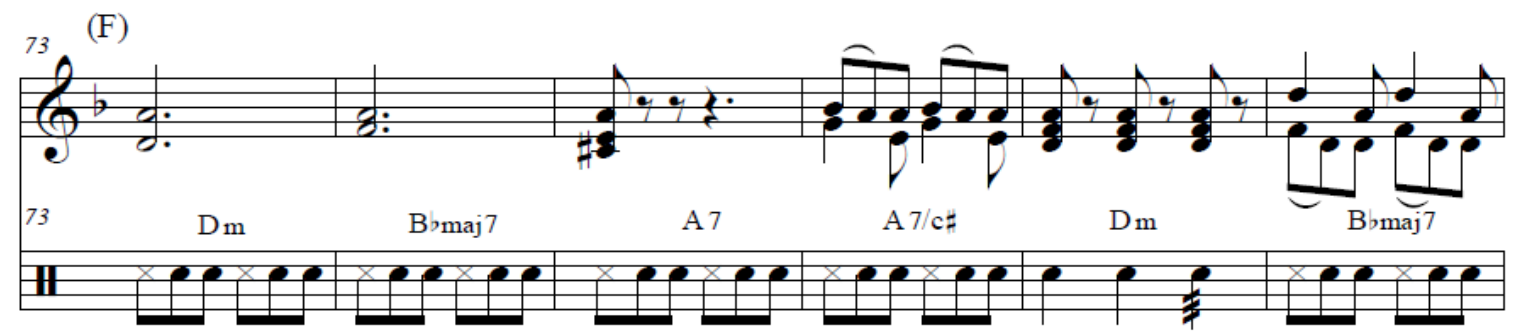

Vln.

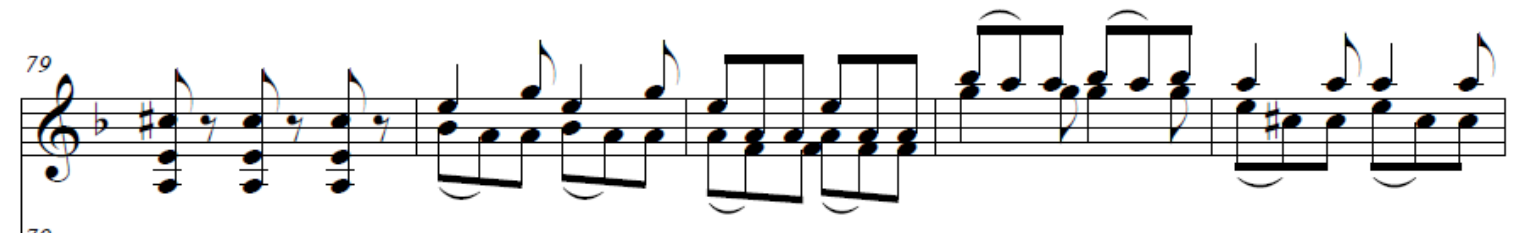

Cuatro

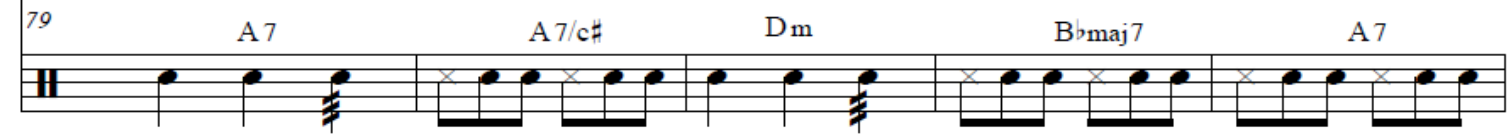

$\mathrm{Vln}$.

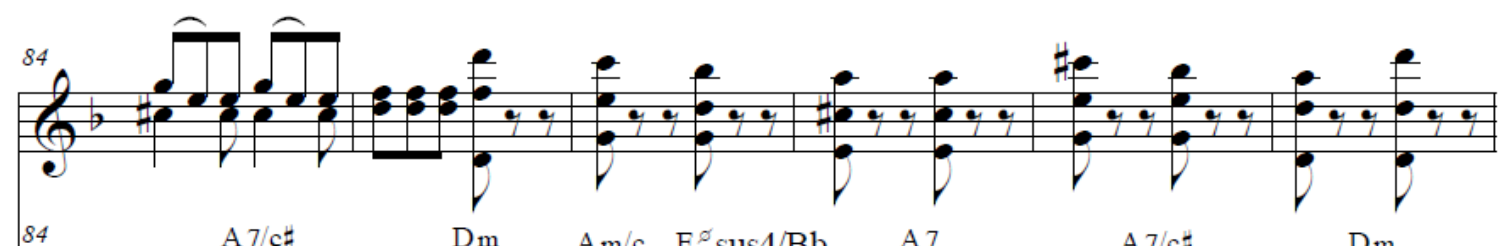

Cuatro

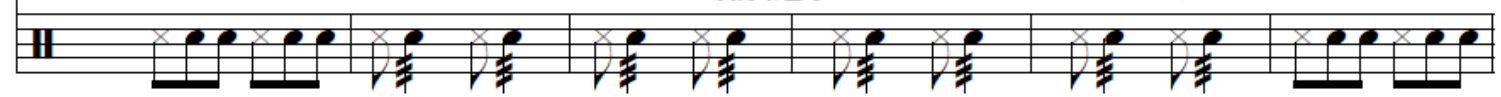

Vln.

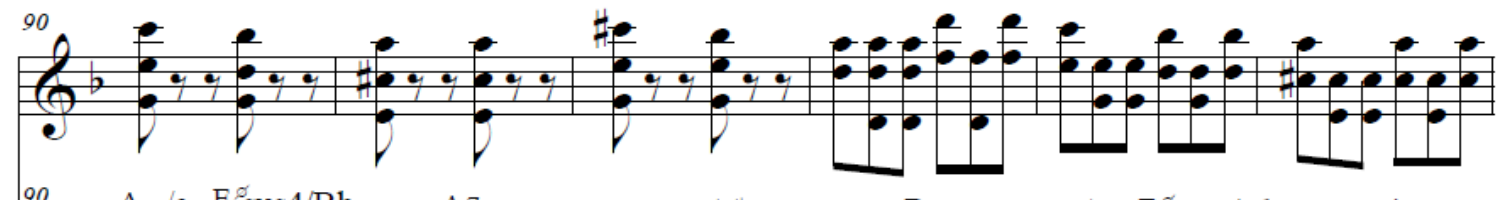

Cuatro

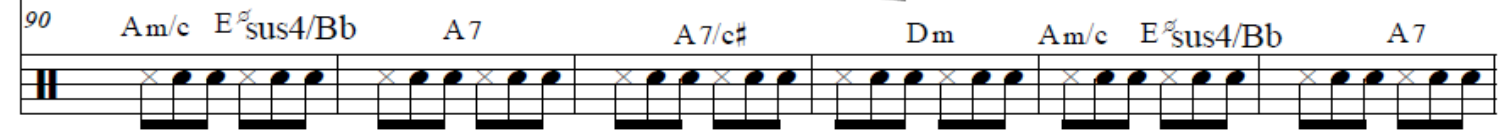

Vln.

Cuatro

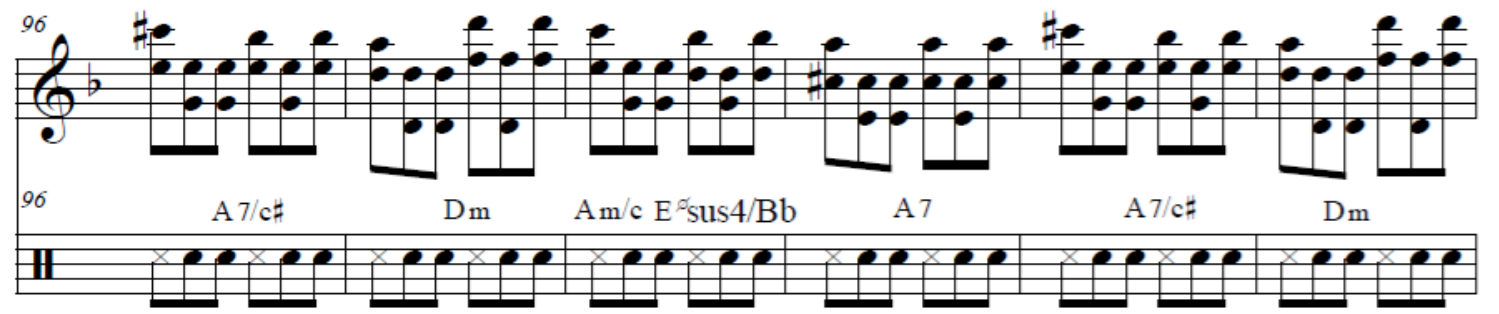




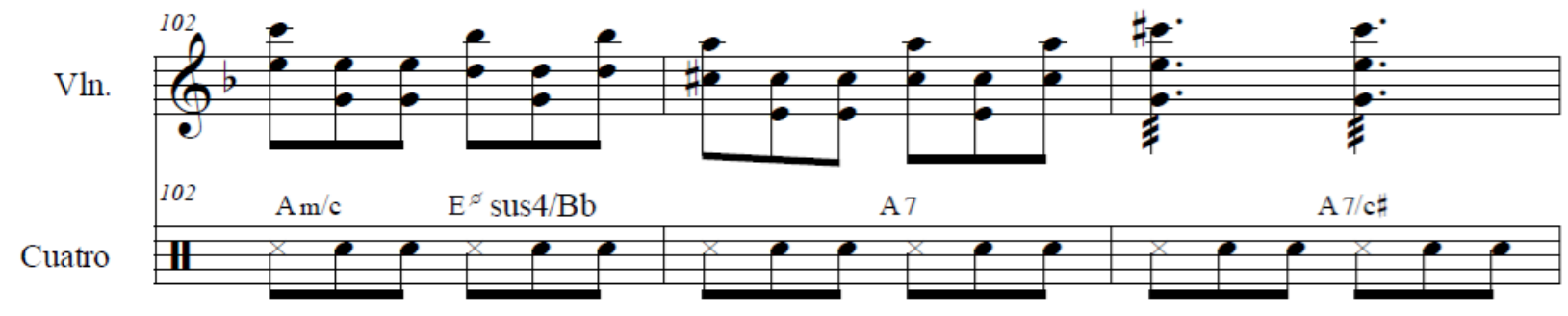

Fig. 12

La última sección de esta parte $(\mathrm{G})^{53}$ consta del final de toda la pieza.

Acá vamos a ver un cambio en las figuras rítmicas tanto del violín como del cuatro, donde se utilizan valores más largos para dar una sensación de reposo. En esta sección se hace uso del segundo tetracordio de la escala menor melódica así que subiendo se mueve utilizando el sexto y séptimo grado alterado (compases 110, 114 y 118), pero bajando utiliza la forma de la escala menor natural con la cadencia frigia de la que hablamos anteriormente (compases 112, 116, 120)

Finalmente después de quedar suspendido en un acorde de dominante (compás 122), el violín resuelve a la tónica ejecutando un arpegio en tres octavas, que se reafirmará en el último compás por el cuatro.

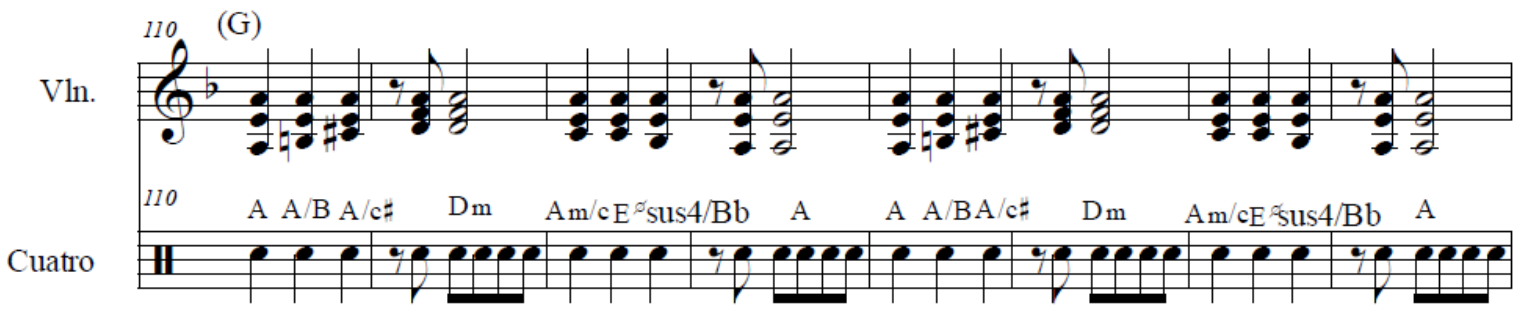

\footnotetext{
${ }^{53}$ Fig. 13. Tercera parte. Sección (G), compases 110 al 126. Del 7’37s al 8’01s
} 


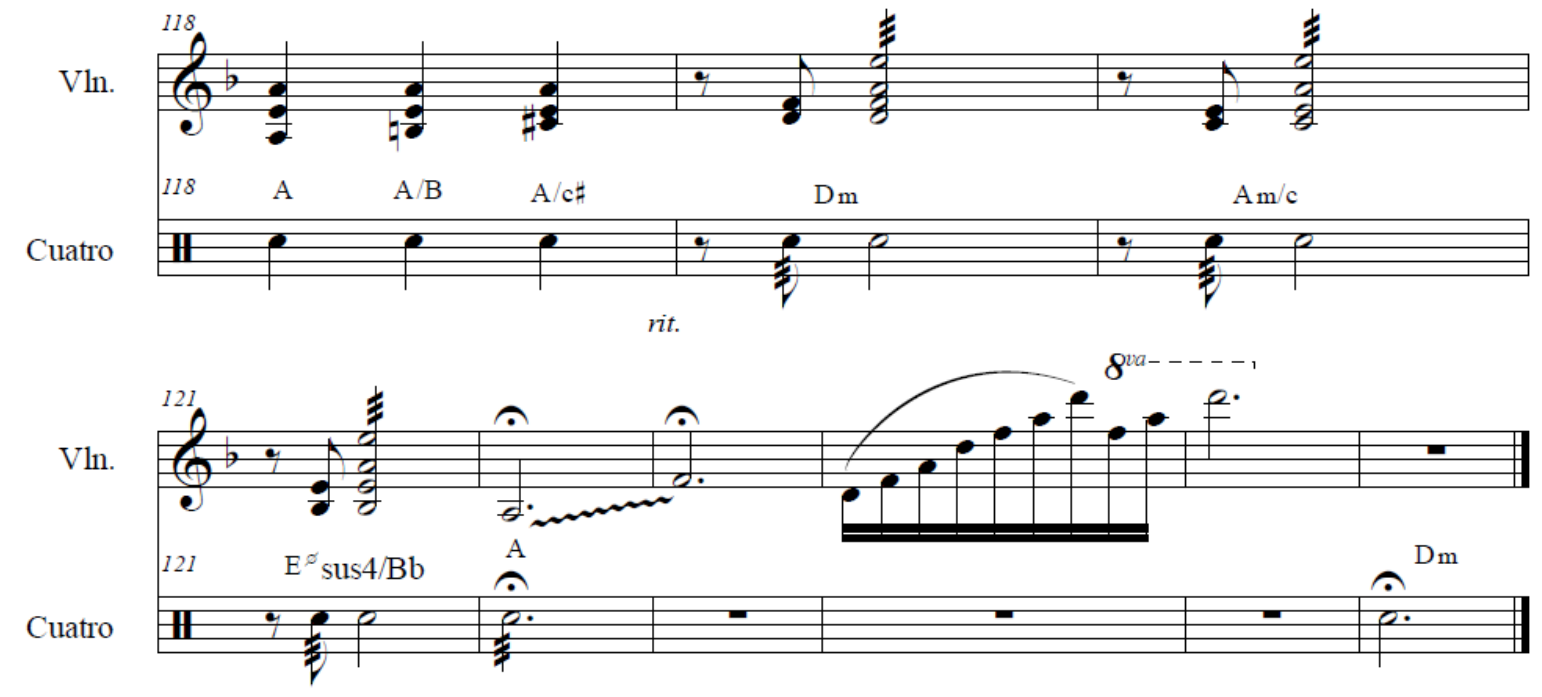

Fig. 13

Podemos destacar que en toda la presentación del pajarillo, Alexis Cárdenas combina la melodía tradicional con elementos de improvisación. El pajarillo es la parte central de la pieza que recoge elementos y motivos de secciones anteriores y que se mueve todo el tiempo entre pasajes melódicos y rítmicos.

Así pues, la combinación de estos planos sonoros (rítmicos, melódicos, armónicos y de improvisación) resulta ser muy importante pues Alexis Cárdenas demuestra su gran versatilidad como intérprete y además exalta las cualidades y posibilidades técnicas del instrumento. Esto sin desconocer el acompañamiento magistral del cuatro que resulta imprescindible para producir un resultado único.

La idea de esta pieza surge porque Alexis Cárdenas quería mostrar sus intereses musicales en una cadenza, a la vez que contar la historia de un viaje que el visualiza como una migración gitana. Cita a Brahms porque es su concierto de violín favorito y porque era un compositor amante de la música popular y folclórica, que recibió mucha inspiración e influencia de la música gitana y húngara. Sugiere más adelante a Bach, pues para él es el compositor más grande, 
complejo y completo que existe y culmina con el pajarillo pues confiesa tener una adoración por el joropo. Encuentra en el ritmo de 6/8 relación con la fuerza de la música marroquí y los pasajes improvisados están inspirados en la música flamenca. ${ }^{54}$

Si hacemos el análisis de los recursos intertextuales, vemos que Alexis utiliza varias técnicas en la construcción de esta pieza. De un lado, cita fragmentos de dos obras muy importantes de la música académica europea (del romanticismo con Brahms y del barroco con Bach), pero aparte de esto hace un collage con ellos, entendiendo a este último como una técnica artística que consiste en ensamblar diversos elementos en un todo unificado. (Delgado, 2012)

Es interesante la manera como Alexis Cárdenas logra yuxtaponer los materiales musicales, ya que aunque no tienen ninguna relación en cuanto al estilo o la época, se mueven y se transforman conservando a su vez su valor formal y de contenido propio.

Hay que destacar también la manera de improvisar ya que a partir de esta elaboración, construye los puentes necesarios para entrelazar las piezas del repertorio europeo con los ritmos tradicionales del folclor de su país.

\footnotetext{
${ }^{54}$ Entrevista a Alexis Cárdenas.
} 


\section{CONCLUSIONES}

La propuesta artística de Alexis Cárdenas recoge lo mejor del ámbito popular y académico de la música actual. De la música popular toma la apertura, la disposición y el riesgo para combinar estilos, así como la re-significación y la hibridación de procedencias y sonoridades, y del académico toma los procedimientos (rasgos intertextuales), la instrumentación, la técnica y el tratamiento formal de las obras. Su música es el encuentro de los principales géneros tradicionales latinoamericanos con el virtuosismo académico y la improvisación.

Él se reconoce como un sujeto mestizo, por eso su proceso creativo se caracteriza por reunir elementos musicales de la herencia europea, indígena y negra. Así, por medio de algunas prácticas apropiacionistas, construye puentes para poder conectar e hibridar lo popular con lo académico y lo antiguo con lo moderno, actualizando y reinterpretando su discurso. En este sentido, vemos que su propuesta no se reduce a hacer una frívola y acrítica estética referencial e historicista; es decir, que no se limita a transferir imágenes, estilos y pautas estéticas a través del tiempo, sino que se ocupa de su reubicación contextual (Prada, 2001).

Su producto musical se fundamenta principalmente en la diversidad de culturas que lo han influenciado, ya que viajó desde muy temprana edad a Estados Unidos y luego a Europa, donde culminó su formación como músico académico y donde reside actualmente. Es un ciudadano del mundo que ha desarrollado un pensamiento intercultural, cosa que le ha permitido enriquecer su experiencia y creatividad.

A su vez, es apasionado de su tradición e identidad latinoamericana y siente la necesidad de seguir explorando y visibilizando las músicas de este territorio. Es así como la hibridación ocurre como resultado de su proceso migratorio y del intercambio comunicacional que propicia el 
encuentro de los sectores musicales hegemónicos con los populares. De este modo, podemos ver claramente hay lugar de negociación entre lo ajeno y lo propio y esa es en sí misma la esencia de su trabajo y el fundamento de su postura estética.

Las motivaciones de Alexis Cárdenas para seleccionar el material que conforma sus piezas, tienen que ver con su deseo de traspasar las fronteras entre lo clásico y lo popular y de moverse con libertad por los géneros que le apasionan. Para el, la buena música no tiene que ver con estratos, categorías o clase, así que no hace ninguna distinción en ese sentido.

A partir de ahí, selecciona los textos y busca puntos en común en cuanto a métrica, patrones rítmicos, giros armónicos y estructuras escalísticas, para crear una nueva puntuación y acentuación a la música. Sin embargo, es cuidadoso en el tratamiento de estos elementos pues quiere cuidar y respetar de alguna manera las formas y los parámetros de estilo del material que ha sido prestado y apropiado.

Alexis Cárdenas utiliza el recurso de la hibridación como forma de producción, y a través de dos de sus estrategias consigue un entrecruce cultural y medial. Lo interesante de este proceso, es que la hibridación permite relacionar y conectar diversos elementos pero no busca reducir su diferencia sino potencializarla. Es decir que por medio de ella se hace intencionalmente un reconocimiento de esa diversidad y de las identidades que la conforman. (Toro, 2005)

La primera estrategia es la teórico cultural y vemos su aplicación ya que en su obra se reúnen géneros musicales procedentes de diferente época, lugar, clase y estilo, con lo cual se hace evidente la conjunción de diversas culturas.

La segunda es la estrategia transmedial que hace referencia a una multiplicidad de posibilidades en cuanto a formas de comunicación y de representación, dando como resultado el diálogo de distintos medios que pueden ser de carácter visual, textual-lingüístico, teatral y 
musical por citar algunos ejemplos. Además, implica un proceder transcultural, transdisciplinario y transtextual ya que se nutre de varios sistemas y subsistemas. (De Toro, 2004)

El procedimiento de hibridación más evidente dentro de la práctica musical de Alexis Cárdenas es el Transtextual, que podemos relacionar con el lenguaje literario y con la categoría de Intertextualidad. Este última, podemos equipararla a la Intermusicalidad donde podemos ver cómo una música ya creada puede llegar a habitar otras músicas. Alexis Cárdenas toma citas de la literatura musical que provienen de diferentes contextos y por medio de recursos como la cita y el collage, aplica técnicas compositivas como el montaje, la superposición y la transformación para generar otro texto nuevo y resignificado.

Las categorías que se analizaron y sistematizaron en este trabajo pueden ser tomadas como punto de partida para otras investigaciones, ya que en la actualidad existen diversas agrupaciones que en sus procedimientos y técnicas de composición trabajan sobre recursos análogos. El tema de las fusiones, mezclas y prácticas de apropiación en la música está muy vigente hoy en día. 


\section{REFERENCIAS}

BARCIA, J. (2001) GERARD GENETTE: “LA OBRA DE ARTE” Y LA INTENCIONALIDAD ESTÉTICA”. En Agora, papeles de filosofía. Universidad de Santiago de Compostela.

BARTHES, R. (1984) El susurro del lenguaje. Más allá de la palabra y la escritura. Cap. II "De la Obra al Texto". Barcelona: Paidós

DELGADO ROMO, J. (Septiembre 2012) "Cita y collage, Literatura e Intertextualidad en Berio”. TERCER MOVIMIENTO DE SINFONÍA (1968). En Espacio Sonoro N. 28.

GARCIA CANCLINI, N. (1997) Culturas Hibridas y Estrategias Comunicacionales. México: Universidad de Colima.

GENETTE, G. (1989) Palimpsestos. Madrid: Taurus

PRADA, J. (2001) La apropiación Posmoderna. Arte, práctica apropiacioncita y teoría de la Posmodernidad. Madrid: Ed. Fundamentos.

STEINER, G. (1993) Presencias reales-Una ciudad secundaria. Barcelona: Ed. EnsayosDestinos.

TORO, A. (2004) Hacia una teoría de la cultura de la 'Hibridez' como sistema científico transrelacional, 'transversal' y 'transmedial'. En: Estudios Literarios \& Estudios Culturales. Nuevo Texto Crítico (Stanford University) 25/26: 275-329

TORO, A. (2005) Pasajes - Heterotopias - Transculturalidad: Estrategias de hibridación en las literaturas latino/americanas: un acercamiento teórico. En: Birgit MertzBaumgartner/Erna Pfeiffer (Hrgs.). Aves de paso: autores latinoamericanos entre exilio y transculturación. (Theorie und Kritik der Kultur und Literatur, Bd. 28). Frankfurt am Main: Vervuert. S. 19-28. 
WALSH, C. (2010) Interculturalidad crítica y educación intercultural. La Paz: Este artículo es una ampliación de la ponencia presentada en el Seminario "Interculturalidad y Educación Intercultural", organizado por el Instituto Internacional de Integración del Convenio Andrés Bello. 


\section{BIBLIOGRAFÍA}

BELINCHE y LARREGLE, (2006) Apuntes sobre apreciación Musical. Editorial de la Universidad Nacional de La Plata (Edulp)

CASCANTE, F (s.f) Hibridación y heterogeneidad en la modernidad latinoamericana: la perspectiva de los estudios culturales.

GENETTE, G. (1997) La Obra de Arte I: Inmanencia y trascendencia. Madrid: Lumen

GONZALEZ, C. (s.f) LA INTERTEXTUALIDAD LITERARIA COMO METODOLOGÍA DIDÁCTICA DE ACERCAMIENTO A LA LITERATURA: APORTACIONES TEÓRICAS. Universidad de Málaga.

GUTIERREZ, R. (2010) Intertextualidad: teoría, desarrollos, funcionamiento. México, Universidad autónoma de Puebla.

HATTEN, R. (1994) El puesto de la intertextualidad en los estudios musicales. En: Criterios, La Habana, $n^{\circ} 32$, p. 211-219

MANSILLA, R. (2013) Rasgos intertextuales en la música académica de la segunda mitad del siglo XX. La cita, la alusión y la parodia como procedimientos arquetípicos y el pasado como archivo en la creación contemporánea. Universidad Nacional de La Plata: Facultad de Bellas Artes, Secretaría de Publicaciones y Posgrado.

MARTI, J. (1998) Músicas Populares. En: Eufonía. Didáctica de la Música' n. 12, Departamento de Musicología. CSIC. Barcelona

NOMO, M. (s.f) Intertextualidad, Influencia, Recepción, Traducción Y Análisis Comparativo. Universidad de Duala, Camerún. 
TORO, A. (2006) "Figuras de la hibridez: Ortiz: transculturación - Paz: hibridismoFernández Retamar: calibán” En: Susanna Regazzoni (Hrsg.): Alma cubana: transculturación, hibridez y mestizaje. The Cuban Siprit: Transculturation, Mestizaje, and Hybridism (Theorie und Kritik der Kultur und Literatur, Bd.). Frankfurt: Vervuert, S. $15-36$ 


\section{DISCOGRAFÍA}

All you need is Love. (The Beatles). Disponible en

[https://www.youtube.com/watch?v=4EGczv7iiEk]

Capricho $N^{o} 16$. Nicoló Paganini (Alexis Cárdenas). Disponible en

[https://www.youtube.com/watch?v=q2-1uC4DRgg]

Capricho $N^{o} 16$. Nicoló Paganini, Versión original para violín solo. Disponible en

[https://www.youtube.com/watch?v=yJKy0LxRPLI]

Cuadros de una Exposición. (Orquestación de Maurice Ravel). Disponible en

[https://www.youtube.com/watch? v=kkC3chi_ysw]

Guaguancó. (Real Charanga). Disponible en

[https://www.youtube.com/watch?v=90OTyDGL2uM]

Kyrie de la missa L'homme arme. (Arreglo de Josquin Des Prez). Disponible en

[https://www.youtube.com/watch?v=DSeFAKwdsmA]

Madrigal Hor che 'l ciel e la terra. (Claudio Monteverdi). Disponible en

[https://www.youtube.com/watch?v=mPhWDKT2gSk] 
Obertura Guillermo Tell. (Giacomo Rossini). Disponible en

[https://www.youtube.com/watch?v=BLXwpGCn2KQ]

Pajarillo Con Moto y Acelerando. (Brahms/Bach/Trad.) (Alexis Cárdenas). Disponible en [https://www.youtube.com/watch?v=P7tLCJLSvZI]

Pajarillo Tradicional. Disponible en

[https://www.youtube.com/watch?v=iqM-60mGkFc]

Pequeña Serenata nocturna de Mozart. (mozART). Disponible en

[https://www.youtube.com/watch?v=gKpFhPdyQLM]

Rondó "Alla turca". (Amadeus Mozart). Disponible en

[https://www.youtube.com/watch?v=JuhSAbQPk7E]

Sonido Bestial. (Richie Ray y Bobby Cruz). Disponible en

[https://www.youtube.com/watch?v=eqwu2NpbQT8]

Surfin USA. (Beach Boys). Disponible en

[https://www.youtube.com/watch?v=2s4slliAtQU]

Suite Española Op. 47. (Isaac Albéniz). Disponible en

[https://www.youtube.com/watch?v=pssZnVi_h2I] 
Variaciones sobre un tema de Haydn Op. 56 (Johannes Brahms). Disponible en

[https://www.youtube.com/watch?v=JcaNYY0SIOI]

Variaciones sobre un tema de Paganini Op. 35 (capricho N. 24) (Johannes Brahms). Disponible en

[https://www.youtube.com/watch?v=1EIE78D0m1g] 


\section{ANEXOS}

En este apartado se encuentra la transcripción a la entrevista realizada a Alexis Cárdenas el 12 de Enero de 2019, con sus respuestas a modo de síntesis para poder destacar así los aspectos centrales de la conversación.

1. ¿A qué edad y dónde comenzó sus estudios de violín?

Rta. Comencé a los 7 años en Maracaibo, con un profesor argentino que tocaba en la sinfónica y en un mariachi. Paralelo a eso, con mi papá hacia música tradicional venezolana y tocábamos en fiestas, parrandas y tertulias. Ahí empecé a entender el placer y el éxito de compartir la música.

2. ¿Dónde culminó sus estudios de violín a nivel universitario? ¿En ese momento que tipo de repertorio interpretaba?

Rta. Me gradué en el conservatorio nacional de París tocando repertorio europeo nada más, no había posibilidad de tocar música latinoamericana en el programa. Eso era impensable hace 20 años.

3. ¿En qué momento decide empezar a interpretar música latinoamericana?

Rta. Vivir fuera me hizo sentir la necesidad de seguir contando lo que aprendí de niño en las parrandas, no quiero dejar de sentir el placer de hacer mi música y de seguir explorando esa herencia. La música clásica me da un placer más racional pero la música latinoamericana fue con la que crecí en mi casa y antes de los grandes escenarios yo me movía tocando con mi padre y disfrutando sin pretensiones. 
4. ¿En este momento con cuantas agrupaciones de música latinoamericana está vinculado? ¿Toca usted en alguna orquesta sinfónica?

Rta. Con mi ensamble Recoveco que está acá en Paris y con un cuarteto cuyos músicos residen en Estados Unidos. Además, soy el concertino de la Orquesta Nacional Ill de France.

5. ¿Cómo surge la idea de empezar a mezclar (hibridar) música académica Europea con música popular latinoamericana? ¿Es un tema de curiosidad, juego, gusto o tiene un trasfondo más político en cuánto a equilibrar en importancia los dos géneros? ¿Fue una idea inspirada por otros compositores que hicieran algo similar?

Rta. En Latinoamérica ya ha habido varios experimentos. Hace como 20 años antes de ir a París escuche el proyecto Bach in Brazil y Mozart en Egipto. También escuché un disco de un maestro en música antigua llamado Abraham Abreu (clavecinista venezolano) donde se inventa que Bach viaja a los llanos, entonces empieza a tocar las Suites pero les pone maracas. Qué lástima que ese disco no salió al mercado.

Yo quiero devolverle a los europeos algo transformado porque ellos están cansados de su propia música, y no porque no tenga un gran valor sino sobre todo por la repetición, así que mi interés es revivirla y reinventarla. Somos herederos de toda esa cultura barroca: Bach, Scarlatti, las iglesias, y hasta la forma de comer. Sin embargo no puedo dejar de bailar, de sentir y de darle mi propia puntuación y acentuación a la música europea porque tengo herencia india y negra que sale.

Soy un transgresor, me gusta cambiar las cosas y a pesar de los esfuerzos del conservatorio por encaminarme, no lo consiguieron. Hice el conservatorio para después desecharlo, sólo tome lo que necesitaba. 
6. ¿Su género se puede considerar como mezcla, fusión, mestizaje o hibridación? ¿Con que concepto se identifica más? ¿Cómo podría definir su propuesta musical?

Rta. Mestizaje es lo que se acerca más, por ahí el veo los puentes entre la herencia europea, la herencia indígena y la herencia africana. El término hibridación no lo había pensado y la palabra fusión no me gusta, me suena a confusión.

7. ¿Cuál ha sido la recepción de su propuesta en los sectores más puristas de la música?

Rta. A algunos colegas les gusta y a otro no, pero en general es bien recibida. En lo personal, mi necesidad artística tiene que ver con mostrarles a los europeos algo distinto, los latinos tenemos que ser capaces de sacarnos la visión tercermundista, dejar de vernos con los ojos de Europa y hacer un nuevo camino.

8. ¿Cómo percibe y cuál es el grado de aceptación de la música latinoamericana dentro de los circuitos académicos en Europa? ¿Hay las mismas oportunidades de difusión o esta música suele interpretarse en otros entornos o espacios menos visibles?

Rta. Estamos en un momento ideal, los europeos necesitan algo nuevo. En París por ejemplo hay mercado para todo y la oferta cultural es increíble. Con mis proyectos me interesa atacar e impactar el mercado y el público de la música clásica, porque ellos ya tienen la referencia musical en el oído y conocen el repertorio.

9. Al hacer la hibridación entre ritmos latinoamericanos y música Europea, ¿Qué elementos musicales tiene en cuenta para su desarrollo? (tratamiento de los materiales sonoros, tratamiento de las texturas, tratamiento rítmico) ¿Cuál es la historia detrás de cada ejemplo?

\section{Capriccio $N^{o} 16$ de Nicolo Paganini}


Rta. La historia de ese capriccio nace de la diversión, de la cuestión lúdica. Paganini siempre ha sido un sufrimiento para los violinistas y en todos los concursos internacionales hay que tocar varios de sus capriccios así que quería imprimirle un elemento divertido. Fue un capricho literal.

En cuanto a lo musical, la acentuación que le da Paganini a este capriccio se asemeja mucho a la línea de un bajo de joropo, así que ahí encontré un elemento en común.

\section{Pajarillo Con Moto y Acelerando (Brahms/Bach/Trad.)}

Rta. La idea del pajarillo nace de un gesto esquizofrénico. Yo me inspiré en Brahms porque es mi concierto de violín favorito y porque además Brahms se inspiró en los gitanos, en la música húngara. Él amaba la música popular y folclórica.

Yo quería contar una historia con mis intereses musicales en una cadencia....Brahms, India, Balcanes, música gitana, flamenco....así que este tema es un viaje, el viaje de los gitanos. Lo concluyo con el pajarillo porque no puedo negar la adoración que tengo por el joropo. La fuerza binaria del 6/8 de nuestro joropo tiene mucha influencia del flamenco en la bulería; que a su vez, está influenciada por la música marroquí, viene de África. El joropo es el ritmo y la fuente en la que baso mi trabajo y de donde parto para construir los puentes que unen a la música latinoamericana con la música europea

Yo trato de ser sobrio en mis experimentos, respeto la música, la tradición. Hay que tener cuidado de no hacer un arroz con mango y salirse del estilo. Ese es mi lado clásico que sale, el de cuidar lo que está. 
10. ¿Conoce los conceptos de Intertextualidad o intermusicalidad? ¿Podría definirlos?

Rta. No

11. ¿Por qué cree que cada vez más agrupaciones latinoamericanas (tanto de música comercial como académica) están trabajando en la actualidad haciendo hibridación de ritmos y géneros? ¿Se tratará de un tema de moda (comercial), de rescatar las músicas tradicionales o de re significar la música con una propuesta que dé como resultado algún género nuevo? ¿Conoce músicos o agrupaciones que estén trabajando en una línea similar? ¿Podría mencionarlos?

Rta. Yo creo que hay de todo, hay artistas que trabajan de corazón y otros que simplemente aprovechan que estas músicas se venden bien. Su actividad se basa en un asunto comercial de adaptación al mercado. Para mí lo ideal es que haya una necesidad de decir algo, un compromiso con las raíces, un gusto, sino solo será moda. 